\title{
The Dutch Consular Court of Izmir
}

\subsection{Adjudication in the Capitulations}

The ahdnames allowed for European ambassadors and consuls to adjudicate legal disputes between the members of their nations, and European traders could count on certain privileges should they have to appear in an Ottoman court. This legal autonomy was already present in the early capitulations. The Ottoman-French treaty of 1535, which contained nineteen articles, stipulated that the French king was allowed to appoint bailiffs or consuls who were allowed to adjudicate disputes among Frenchmen without interference from an Ottoman tribunal. ${ }^{1}$ Some of the early French capitulations included the clause that litigants belonging to the same European nation could appear before an Ottoman court, but only at the expressed wish of their ambassador. Trials between a Frenchman and an Ottoman subject were to be heard at an Ottoman court, but always in the presence of an interpreter. ${ }^{2}$

The English capitulations of 1580 contained similar clauses on legal autonomy, granting English ambassadors and consuls the right to adjudicate disputes between Englishmen on the basis of English legal custom. ${ }^{3}$ Similar arrangements were given to the Dutch in the 1612 capitulations: ${ }^{4}$

[Article 5] If lawsuits and hostility, cases of murder and blood money occur among those from the Dutch Provinces, their ambassador and consul should see to it according to their customs and decide the case; no qadis or legal officers should interfere. ${ }^{5}$

1 Paul Masson, Histoire du commerce français dans le Levant au XVIIe siècle (Paris, 1896), p. xii.

2 Ibid.

3 Skilliter, William Harborne, p. 88; see also Herbert J. Liebesny, 'The development of western judicial privileges', in Origin and development of Islamic law, vol. 1 of Law in the Middle East, eds. Majid Khadduri and Herbert J. Liebesny (Washington, 1955), pp. 309-333.

4 For a transcription into modern Turkish and an English translation of the Dutch capitulations of 1612, see de Groot, The Ottoman Empire, pp. 138-157. The translations included here are de Groot's.

5 Ibid., p. 15 o.

(C) TIJL VANNESTE, 2022 | DOI:10.1163/9789004498235_004

This is an open access chapter distributed under the terms of the CC BY-NC 4.o license. 2 Vanneste - 9789004498235 Downloaded from Brill.com04/26/2023 10:18:11AM 
[Article 6] When any persons enter upon a lawsuit [before the qadi] against the consuls appointed for the merchants' affairs, the consuls may not be put under arrest nor their houses be sealed. Their law suits involving consuls and dragomans must be heard at our threshold of felicity. ${ }^{6}$ [Article 36] If, in the case of a dispute, someone goes to the qadi and the dragoman of the Dutch is not present, the qadi may not hear the case. If it is about important affairs, the case shall be adjourned till the coming [of the dragoman]. But they may not seek an excuse and try to cause delay by saying: 'our dragoman is not present. ${ }^{7}$

These articles provided the formal expression of Dutch legal autonomy and allowed the consular and ambassadorial courts to operate independently from Ottoman justice, at least in cases involving members of the Dutch trading community. Several jurisdictional issues remained. Disputes involving Ottomans were to be heard at the local qadi courts, which were entitled to adjudicate both civil and criminal matters and which also had the competence to act as mediator and notary. The Imperial Council in Istanbul, the diwan-i hümayun, was the Ottoman Empire's highest court, and any Ottoman subject was allowed to seek recourse to this court, although a plaintiff would have to travel personally to Istanbul, a practical impediment that led to decisions regularly being referred back to the qadi courts. ${ }^{8}$ Several early capitulations specified that the Imperial Council was the competent court in a number of specific cases that involved foreigners. These included murder (first mentioned in the French capitulations of 1536), cases worth over 4,000 aspers (English capitulations of 1601) and cases involving consuls or dragomans (French capitulations of 1604$) \cdot{ }^{9}$

Because the capitulations were treaties between a specific European power and the Ottoman Empire, they did not include a solution to the problem of jurisdiction regarding a dispute that involved Europeans belonging to different nations. European consuls and ambassadors in the Levant had agreed to use the Roman principle of actor sequitur forum rei, meaning that the defendant was entitled to adjudication at the court under whose jurisdiction he fell. ${ }^{10}$

Ibid., pp. 150-151.

Ibid., p. 154 .

Van den Boogert, The capitulations, pp. 47-52.

Ibid.

10 This was common European legal practice based on Roman law. It can be found in the Codex compiled by Justinianus, containing the imperial constitutiones from the second century until its publication in 534. It is referred to under the heading 'Imperatores 
During the Middle Ages, when legal fragmentation was widespread, several bourgeoning European political entities adopted the forum rei principle as a means to determine jurisdiction regarding disputes that involved litigants coming from different towns or regions. ${ }^{11}$ In the Ottoman context, forum rei was initially adopted on the basis of informal agreements between Europeans. They accepted to bring intra-European disputes in first instance before the consul of the defendant and to bring appeals before the ambassador of the defendant. ${ }^{12}$ The first sign of recognition of the practice by the Porte can be found in the French capitulations of 1740:

Article 52. S'il arrive que les consuls et les négociants français aient quelques contestations avec les consuls et les négociants d'une autre nation chrétienne, il leur sera permis, du consentement et à la réquisition des parties, de se pourvoir par-devant leurs ambassadeurs qui résident à ma Sublime Porte; et tant que le demandeur et le défendeur ne consentiront pas à porter ces sortes de procès par-devant les pachas, kadis, officier ou douaniers, ceux-ci ne pourront pas les $\mathrm{y}$ forcer, ni prétendre en prendre connaissance. ${ }^{13}$

Article $5^{2}$. If it should be so that the French consuls and merchants have some disputes with the consuls and merchants of another Christian nation, they will be allowed, with consent and at the requisition of all parties involved, to appear before their ambassadors who reside at my Sublime Porte; and in case the plaintiff and defendant do not consent to take such trial before the pachas, qadis, officers or customs officers, these [pachas, qadis, officers or customs officers] cannot force them to do so, nor pretend to take notice of it. ${ }^{14}$

Gratianus, Valentianus, Theodosius'. The full article is as follows: 'Actor rei forum, sive in rem sive in personam sit actio, sequitur. sed et in locis, in quibus res propter quas contenditur constitutae sunt, iubemus in rem actionem adversus possidentem moveri'. The Codex, as well as the two other Justinian compilations that make up the Corpus iuris civilis, can be consulted online at http://www.thelatinlibrary.com/justinian.html.

11 'Actor sequitur forum rei', in Aaron X. Fellmeth and Maurice Horwitz, eds., Guide to Latin in international law (Oxford, 2009), consulted online at http://www.oxfordreference.com/ view/10.1093/acref/9780195369380.oo1.ooo1/acref-978o19536938o-e-76.

Van den Boogert, The capitulations, p. 36. An early mention of the agreement between European consuls to apply the forum rei principle was in a letter sent by the Dutch consul in Aleppo, Cornelis Pauw, to the States General in 1615 about the abuses of the Dutch traders in that city against the consul's jurisdiction. See pp. 91-93.

13 Bianchi, Le nouveau guide, p. 274.

14 The last part of the phrase is unclear and would make more sense if another denial was added to it: 'these [pachas, qadis, officers or customs officers] cannot force them to do so, nor pretend not to take notice of it'. 
This was the first time any capitulations contained a clear set of instructions on the proper handling of intra-European disputes. Several other articles of the 1740 capitulations dealt with adjudication: ${ }^{15}$

Article 15. S'il arrivait quelque meurtre ou quelque autre désordre entre les Français, leurs ambassadeurs et leurs consuls en décideront selon leurs us et coutumes, sans qu'aucun de nos officiers puisse les inquiéter à cet égard. ${ }^{16}$

Article 15. If a murder or any other disorder happens among the French, their ambassadors and their consuls will decide upon it on the basis of their usages and customs, and none of our officers can disturb them in that regard.

Article 16. En cas que quelque personne intente un procès aux consuls établis pour les affaires de leurs marchands, ils ne pourront être mis en prison, ni leur maison scellée, et leur cause sera écoutée à notre Porte de félicité; et si l'on produisait des commandements antérieurs ou postérieurs contraires à ces articles, ils seront de nulle valeur, et il sera fait en conformité des capitulations impériales. ${ }^{17}$

Article 16. In the case that anybody intends to go to trial against the established consuls regarding the affairs of their merchants, they [consuls] cannot be put in prison, their houses cannot be sealed, and their cause shall be heard at our Threshold of Felicity; and if one was to provide commandments, of an earlier or later date than these articles, they shall be of no value, and it will be done in conformity to the imperial capitulations.

Article 26. Si quelqu'un avait un différend avec un marchand français, et qu'ils se portassent chez le kadi, ce juge n'écoutera point leur procès, si le drogman français ne se trouve présent; et si cet interprète est occupé pour lors à quelque affaire pressante, on différera jusqu'à ce qu'il vienne; mais aussi les Français s'empresseront de le représenter, sans abuser du prétexte de l'absence de leur drogman. Et s'il arrive quelque contestation entre les Français, les ambassadeurs et les consuls en prendront

15 These capitulations were chosen as an example because they were the first to contain the forum rei and the 'most favoured nation' principles, ensuring their relevance for capitulations of the other European nations. Additionally, the date they were issued is close to the dates of the disputes that will be investigated as case studies in this monograph, and a full and accurate translation of them into a European language has been published.

16 Bianchi, Le nouveau guide, pp. 264-265.

17 Ibid., p. 265. 
connaissance, et en décideront selon leurs us et coutumes, sans que personne puisse s'y opposer. ${ }^{18}$

Article 26. If someone has a difference with a French merchant, and if they go to the qadi, this judge will not hear the trial unless the French dragoman is present. And if this interpreter is occupied at the time of a pressing matter, the case will be delayed until he comes; but the French will also hurry to represent the matter without abusing the pretext of the absence of their dragoman. And if any dispute occurs between the French, the ambassadors and consuls shall take notice of it, and they will decide according to their use and custom, without anyone able to oppose it.

Article 41. Les procès excédant quatre mille aspres seront écoutés à mon divan impérial, et nulle part ailleurs. ${ }^{19}$

Article 41. Trials concerning monetary sums exceeding 4,000 aspers will be heard at my Imperial Divan, and nowhere else.

Article 69. Si un marchand français voulant partir pour quelque endroit, l'ambassadeur ou les consuls se rendent sa caution, on ne pourra retarder son voyage, sous prétexte de lui faire payer ses dettes; et les procès qui les concernent, excédant quatre mille aspres, seront renvoyés à ma Sublime Porte, selon l'usage, et conformément aux capitulations impériales. ${ }^{20}$

Article 69. If a French merchant wants to leave for any place, the ambassador or the consuls will provide a security deposit for him, and his voyage cannot be delayed on the pretext of forcing him to pay his debts first; and trials concerning those debts higher than 4,000 aspers will be sent to my Sublime Porte, according to legal use, and the imperial capitulations.

Articles 15 and 26 were repetitions of the well-established legal autonomy that already existed in earlier capitulations for different nations. ${ }^{21}$ Articles 16 and 69 had historical equivalents in earlier French, Dutch and English capitulations.

\footnotetext{
18 Ibid., pp. 267-268.

19 Ibid., p. 272. These values were quickly outdated as they were not adapted to the changing monetary value, and their presence in the capitulations lost relevance, something the translator of these capitulations was well-aware of.

20 Ibid., p. 280.

21 The Dutch equivalent of article 26 , however, only mentioned the obligation to have dragomans present at qadi hearings involving a Dutchman. De Groot, The Ottoman Empire, p. 154 .
} 
Although European consuls and ambassadors were granted legal autonomy, there was nothing in the capitulations that prevented Europeans from seeking recourse to an Ottoman court. ${ }^{22}$ Maurits van den Boogert pointed out that article $5^{2}$ was used to reintroduce the option of appearing before an Ottoman court, should the involved parties desire to do so. It was an option that had been included in earlier French capitulations, but not in those granted to other states. ${ }^{23}$ It was, however, an option that was strongly discouraged by European consuls and ambassadors, for fear of setting a precedent or having their subjects involved in trials under a foreign jurisdiction with unpredictable outcomes.

Even though European custom was clear, forum rei still led to quarrels; in 1730, the Dutch ambassador in Istanbul, Cornelis Calkoen, wrote to Fagel, an official at the States General, about the furious letters he received from the French ambassador concerning a dispute regarding damages suffered by the vessel of a Dutch skipper named Isaac Haverman. ${ }^{24}$ Upon arrival in Salonika, he refused to unload before the issue of financial responsibility for the damage was settled, but the owners instructed him to unload first and promised to pay afterwards. Several French merchants whose goods were on board objected, which led to a legal dispute before the Dutch consul in Salonika. According to Calkoen, his sentencing did not please the Frenchmen, who then appealed before the Dutch ambassador in Istanbul. This made the French ambassador furious, writing to his Dutch colleague that he would never allow Frenchmen to seek justice before the Dutch ambassador; he wanted to try the Dutch ship owners himself. ${ }^{25}$ Calkoen found the French ambassador's outrage unjustified, also because it might create legal confusion that the Ottomans might use to extend their jurisdiction to this type of dispute. ${ }^{26}$

\subsection{The Establishment of Consular Jurisdiction}

The capitulations made the Dutch consuls in the Ottoman Empire judges, able to adjudicate on the same basis as courts in the United Provinces. This was neither strange nor new as, since the Middle Ages, consuls had adjudicating powers in disputes involving members of the community over which they

\footnotetext{
22 Van den Boogert, The capitulations, p. 42.

23 Ibid., p. 36. A similar phrasing can be found in article 26, which confirmed the legal autonomy of Europeans, but not before pointing out the possibility of resorting to a qadi court.

24 Heeringa and Nanninga, Bronnen tot de geschiedenis, 3: pp. 27-29, Ambassador Cornelis Calkoen to Fagel, Istanbul, o8/11/1730.

25 Ibid.

26 Ibid.
} 
had jurisdiction. ${ }^{27}$ The institution of the consulate had developed in Venice, Genoa, Ancona and Florence to fill the need of a legal mediator between a host city and a foreign trading community. ${ }^{28}$ Consular courts existed in several commercial cities in northwestern Europe as well. Foreign trading communities in Bruges, a crucial commercial centre in the late Middle Ages, had consular courts since 1309, and by 1450, ten of the fourteen foreign nations in Bruges were given their own consular jurisdiction by the city. ${ }^{29}$ The granting of consular jurisdiction coincided with a late medieval expansion of adjudication, also in the Low Countries, which led to a growing need for specific legislation codifying the jurisdiction and procedure of litigation for specific courts. A great deal of this legislation was issued during the 'legal revolution' of the sixteenth century, which was also considered a peak period for litigation. ${ }^{30}$ It was a period of the rationalisation of procedure, development of appeal procedures, bureaucratisation of the legal apparatus and development of the professional branch of lawyers. ${ }^{31}$

In 1612, when the first Dutch ahdnames explicitly allowed for Dutch legal autonomy, many of the legal procedures at local courts in the United Provinces had been codified in local law. ${ }^{32}$ The next logical step was to integrate the consulates in the Ottoman Empire into existing legislation on how courts functioned in the United Provinces. The first consulate regulations, published by the States General following the appointment of Cornelis Pauw as consul of Aleppo in December 1612, were not very explicit on adjudication. One stated only that the consul's secretary, as well as those of other consuls, would have to pass along all requested documents on behalf of merchants - and these

27 See Paola Volpini, 'La trattatistica sulla figura del console nella prima età moderna. Spunti di ricerca', in Los cónsules, eds. Aglietti et al., pp. 35-45; and Géraud Poumarède, 'Le consul dans les dictionnaires et le droit des gens: Émergence et affirmation d'une institution nouvelle (XVIe-XVIII ${ }^{\mathrm{e}}$ siècles)', in La fonction consulaire à l'époque moderne. L'affirmation d'une institution économique et politique (1500-180o), eds. J. Ulber and G. Le Bouëdec (Rennes, 2006), pp. 23-36.

28 Mariya Tait Slys, Exporting legality. The rise and fall of extraterritorial jurisdiction in the Ottoman Empire and China (Genève, 2014), pp. 14-15.

29 Gelderblom, Cities of commerce, pp. 109-111.

30 The term 'legal revolution' was coined by Richard L. Kagan in reference to the expansion of litigation. Richard L. Kagan, Lawsuits and litigants in Castile, 1500-1700 (Chapel Hill, 1981). For the Dutch case, see Marie-Charlotte Le Bailly, 'Langetermijntrends in de rechtspraak bij de gewestelijke hoven van justitie in de Nederlanden van ca. 145 o tot ca. 180o', Pro memorie: Bijdragen tot de rechtsgeschiedenis der Nederlanden, 13:1 (2011): pp. 3067 , particularly pp. 30-31.

31 Le Bailly, 'Langetermijntrends'.

$3^{2}$ See pp. 119-137. 
included deeds of legal procedures as well as sentences. ${ }^{33}$ The resolutions of the meetings held by the States General in that period are much clearer on the matter, and in a meeting that took place on 8 December 1612, it was decided that 'together with his assessors, he [Cornelis Pauw] will try to settle all disputes brought before him amicably, or, in case the parties want to adjudicate a dispute, to come to a sentence in a neutral manner. ${ }^{34}$ A new official letter of appointment for Pauw that was issued by the States General in May 1614 explicitly authorised him to adjudicate all civil and criminal matters brought before him and to choose assessors from amongst the Dutch merchants settled in Aleppo to assist him. ${ }^{35}$ The assessors were assistant-judges, and as such, they fulfilled a crucial role in adjudication. ${ }^{36}$ It is worth noting that the French had a similar system, in which the consul-as-judge was assisted by four notable merchants, but the French consul often had difficulties finding willing traders, which could have been related to the fact that these merchants were employees of larger firms in Marseille. ${ }^{37}$

It did not take long before Cornelis Pauw came into conflict with Dutch Levant traders, at home as well as in Aleppo. Pauw complained that his expenses were too high and his income through consular duties too low, while traders in the United Provinces felt Pauw was too young, incompetent and selfish. Levant traders in Zeeland were most adamant, criticising Pauw for not having gone to university and for having no experience in commerce. Several merchants felt Pauw had obtained his post because of his father's influence and not because of his own capabilities. ${ }^{38}$ The conflict was further aggravated by Pauw's feelings that his adjudicating authority was challenged. In September 1615, he explained in a letter to the States General that it was common for Ottomans to turn to European consular justice in Aleppo because of the high cost involved

33 Cau, Groot placaet-boeck, 2: pp. 1333-1334, 'Acte', o8/12/1612.

34 Van Deursen, ed., Resolutiën der Staten-Generaal, 1: p. 794, Meeting States General, o8/ 12/1612, 'Hij zal met zijn assessoren trachten alle geschillen die hem voorgelegd worden in der minne te schikken, of, indien partijen de zaak berecht willen hebben, onpartijdig uitspraak te doen'.

35 Heeringa and Nanninga, Bronnen tot de geschiedenis, 1: pp. 444-446, 'Commissie voor Cornelis Reyniersz Pauw als consul in Aleppo, Syrie etc.', 30/05/1614.

36 The manner of their selection was part of the ongoing quarrels between Dutch consuls and merchants in seventeenth-century Izmir. See pp. 94-95.

37 Mason, Histoire du commerce, p. 446.

38 See several petitions made against Pauw in Heeringa and Nanninga, Bronnen tot de geschiedenis, 1: pp. 444-462. It seems the authorities did not agree, as Pauw was maintained as consul until 1625, after which he was active as envoy in Sweden and Germany. In 1632 he entered the service of Frederik Hendrik, prince of Orange. Schutte, Repertorium der Nederlandse vertegenwoordigers, pp. 176-177. 
in going to the qadi court, and because of the European threat of issuing a boycott of Ottoman traders who refused to be tried by a European court. ${ }^{39}$ The consul used the term battelatie to indicate an embargo issued by a community against trading with a specific merchant or group of merchants. While a known concept, the word is hard to translate: 'this procedure known as battelation, prohibited any contact with the boycotted merchant on pain of a fine. When one European community announced a battelation, solidarity was expected from all other European merchants until the embargo was lifted'40 It was not an exclusive European practice, but European trading communities in the Levant used it to discourage Ottomans from cheating European traders. At the end of his letter, Pauw included an example of a battelatie:

We, Cornelis Pauw, on behalf of the gentlemen of the States General of the United Dutch Provinces consul in Syria etc. by our command and at the instance of the honourable Daniel van Goethem, [order that] Hagi Nureddin and Abdel Agi, Moorish merchants, remain battelated with all their goods and merchandise, [we] forbid all and everyone, particularly our own [subjects] to make a contract or trade with them, as well as the brokers, who will [not] conduct any brokerage with them, on the penalty that the transgressor shall pay 500 reals of eight. ${ }^{41}$

39 Heeringa and Nanninga, Bronnen tot de geschiedenis, 1: pp. 468-478, Consul Cornelis Pauw to the States General, Aleppo, 12/og/1615.

40 Maurits van den Boogert, 'European patronage in the Ottoman Empire: Anglo-Dutch conflicts of interest in Aleppo (1703-1755)', in Friends and rivals, eds. Hamilton et al., p. 214. It remains unknown where the word comes from. The only reference I found was in a work about the travels of a nobleman from Gent, Joos van Ghistele, that was first published in 1557. He travelled in North Africa, the Mediterranean and the Middle East between 1481 and 1485 , and his experiences were written down by a certain Ambrosius Zeebout. When the text discusses marriage and divorce in Islam, it uses the word 'batteleren', a verb, to refer to a form of divorce, and a footnote compares this with the Arabic word talāq, which was historically a controversial form of divorce in which the man repudiated the woman. Ambrosius Zeebout, Tvoyage van Mher Joos van Ghisele, ed. R.J.G.A.A. Gaspar (Hilversum, 1998), p. 15; and Maaike Voorhoeve, Abed Awad and Hany Mawla, 'Divorce', in The Oxford encyclopedia of Islam and women, ed. Natana J. de Long-Bas (Oxford, 2013), consulted online at https://www.oxfordreference.com/view/10.1093/acref:oiso/ 9780199764464.001.00o1/acref-9780199764464-e-o1o8?rskey=jinXdZ\&result=1. It is possible that battelatie comes from talāq and has taken the negative connotation of 'repudiation' from it.

41 Itself published on 20 August 1615 , the translation was included at the end of a long letter in Heeringa and Nanninga, Bronnen tot de geschiedenis, 1: pp. 468-478, Consul Cornelis Pauw to the States General, Aleppo, 12/og/1615, on p. 478, 'Wij, Cornelis Pauw, van wegen de H.M. heeren de Staten-Generael der Vereenichde Nederlantsche Provinciën consul in Soria etc., door ons bevel ende ter instantiën van den eersamen Daniël van Goetthem, 
Five days later, the boycott was lifted after Nureddin and Agi gave 'satisfaction to our justice.'42 Pauw's letter confirmed that Ottomans were aware of this practice and acted accordingly by choosing European over Ottoman justice. This acceptance of European courts, including the Dutch consular court, was good for the Dutch merchant community and for the consul, who could strengthen his legal authority by adjudicating a larger number of disputes. But according to Pauw, Dutch traders were abusing this practice. They litigated against 'Turks, Persians and Armenians', and even if they were in the wrong, they pressured their consul to issue a verdict in their favour. ${ }^{43}$ In a case where the consul was unwilling to comply, several Dutch merchants threatened to take the matter before an Ottoman court, directly challenging the consul's legal authority, as well as his impartiality. ${ }^{44}$

Pauw made it clear that this posed a very serious threat to the consular system of adjudication, and the States General responded by issuing additional legislation in 1616, which was substantially more extensive than the paragraphs on adjudication that had been issued in 1612 and 1614. The States General's response to the conflict between the consul and the merchants in Aleppo became the model for all future legislation issued in regard to consular adjudication in the Levant, in the sense that regulations focussed on competence and procedure and were mostly issued as a posteriori responses to very concrete problems of jurisdiction and procedure as they occurred within the Dutch Levantine trading communities. A meeting held on 17 February made it clear that the States General felt that Pauw's authority needed formal support, and an ordinance on adjudication was published the same day. ${ }^{45}$

One of the first important stipulations was that consular sentences on litigation between Dutchmen and members of other communities (either European or Levantine) could not be appealed and would go into immediate effect. Verdicts in disputes that only involved Dutch subjects were to be executed under 'provision' (provisie) or 'caution' (cautie), meaning appeal was possible,

blijven gebatteleert Haggi Noredin ende Abdelagi, Moorsche cooplieden, met alle haere goederen ende coopmanschappen, verbiedende aen allen ende een yegelijcken in't besonder van de onse, met deselve te contracteren oft te handelen, van gelijcken aen alle de maeckelaers, die met deselve sullen doen eenige soorte van maeckelaerdije, op pene dat den overtreder van sijn eygen sall betaelen vijffhondert realen van achten'.

42 Ibid.

43 Ibid., p. 469, '[...] Turcken, Persianen, Armenen [...]'.

44 Ibid.

45 Van Deursen, ed., Resolutiën der Staten-Generaal, 2: p. 581, Meeting States General, 17/ o2/1616; Cau, Groot placaet-boeck, 2: pp. 1335-1338, 'Acte, voor den consul van Aleppo, noopende de judicature, \&c.', 17/o2/1616. 
but a sum had to be deposited in the consular chancery by the convicted party as a guarantee. Appeal was not possible in cases concerning 'excesses, delicts, or public scandals. ${ }^{46}$ The exact meaning of these terms is not clear, but there was an important distinction in procedure between civil and criminal cases. In the latter, defined as 'delicts subject to corporal punishment', the consul was only authorised to arrest the offender, chain him in iron chains and send him back to the United Provinces on the first homebound vessel - a fate also awaiting those refusing to obey the consular orders. ${ }^{47}$ In civil cases, he had to adjudicate on the spot. ${ }^{48}$

A third important element was concerned with the appointment of two assessors. The consul had to choose them from amongst the three foremost merchants - nominated by their peers - of the local Dutch trading community. Their task was to assist the consul in fostering commerce and in adjudicating legal disputes involving matters of 'greater importance' 49 The decision to employ merchants as co-judges was not uncommon for a commercial court, and because the consul - who could not be a merchant himself - was first of all responsible for fostering trade and the Dutch community he held authority over was a community of merchants, the consular courts in the Levant were essentially commercial courts..$^{50}$ In the end, the 1616 ordinance was an exercise in balancing consular authority with commercial interest.

The appointment of the assessors continued to be used as currency in disputes between Dutch consuls and merchants, particularly in Izmir. In 1657, a new consul was appointed there, Michel du Mortier from Leiden. ${ }^{51}$ Despite the fact that he was the first Dutch-born consul in Izmir, at the specific request of the Dutch merchants there, he quickly ran into conflict with the Dutch trading community when it came to his consular duties. In 1658 , the States General issued legislation in an attempt to end the dispute, and part of it dealt with

46 Cau, Groot placaet-boeck, 2: pp. 1335-1338, 'Acte, voor den consul van Aleppo, noopende de judicature, \&c., 17/02/1616, on p. 1335, '[...] excessen, delicten ofte publijcque schandalen $[\ldots]$ '.

47 Ibid., p. 1337, '[...] delicten aenden lyve strafbaer [...]'.

48 Ibid.

49 Ibid., p. 1338, ‘[...] van grooter importantie [...]'. Although it is not clear from the text what these matters were, later adjustments indicate that it was determined on the basis of the monetary value of the dispute.

$5^{\circ}$ For an extensive analysis of the functioning of commercial courts in the early modern period, see Kessler, The Parisian merchant court. England did not establish such courts. Christian R. Burset, 'Merchant courts, arbitration, and the politics of commercial litigation in the eighteenth-century British Empire', Law and history review, 34:3 (2016): pp. 615-647. Schutte, Repertorium der Nederlandse vertegenwoordigers, p. 332. 
consular adjudication..$^{52}$ While the adjudicating role of the assessors, chosen as three of the 'most notable, most qualified and most modest merchants of the Dutch nation', was confirmed, their appointment was now fully the prerogative of the consul, and the procedure in which the trading community nominated them was abolished. ${ }^{53} \mathrm{An}$ additional stipulation was that the assessors were not allowed to adjudicate in cases in which they carried an interest; in the rare event that the whole Dutch trading community was involved in a case, the consul had to look for three of the most qualified merchants from another European trading community in Izmir. ${ }^{54}$ Such requirement is further evidence of the pragmatism that easily crossed national boundaries and was attached to the merchants' style. It is clear that the States General, as they had done in 1616 during the Aleppo dispute, sided with the consul and protected his authority; as a consequence, the role of the trading community in choosing their own cojudges by nominating assessors was curtailed.

\subsection{A Proposal to Codify Adjudication in the Levant}

The measures taken by the States General in conflicts in Aleppo and Izmir were aimed at settling several issues within the Dutch trading communities, not only legal matters but also quarrels on taxes and remunerations. Particularly in the case of Izmir, legislation did not fully succeed in halting the quarrels until the arrival of the first consul from the de Hochepied family. Before then, Jacob van Dam had been the longest serving Dutch consul in Izmir, serving for almost twenty years. ${ }^{55}$ His consulate was characterised by the most serious quarrels between Dutch consuls and merchants, and it was in reaction to his tenure that the States General decided to issue more profound legislation than they had done up to that moment. Next to van Dam's unjust claims on the merchants' money and his harsh treatment of some of his subjects, the Dutch traders in Izmir also accused the consul of sloppy adjudication. ${ }^{56}$ Their complaint was taken seriously and led to an extensive attempt at codification of the legal powers of the Dutch consuls in the Levant.

$5^{2}$ For the quarrels in Izmir and the 1658 response to it, see pp. 49-51.

53 Heeringa and Nanninga, Bronnen tot de geschiedenis, 2: pp. 156-158, 'Resolutie der StatenGeneraal tot nederlegging der geschillen in Smyrna', 24/07/1658, on p. 158, ‘[...] drie van de notabelste, gequalificeerste ende bescheydenste coopluyden van de Nederlantsche natie [...]' The regulation was reconfirmed on 18 September 1670.

54 Ibid.

55 See pp. $5^{\mathrm{O}-5^{2} \text {. }}$

56 Van Dam van Isselt, 'De klachten', p. 314. 
New legislation was to serve a double purpose: first, it should settle once and for all the discussions on ambassadorial and consular duties by providing the diplomats with a fixed monetary recompense, to be paid out of a special register, for which several taxes would be collected; second, it had to define the duties and rights of diplomats and traders in the Levant, including regulations on litigation, in order to ensure a peaceful and smooth daily management of Dutch affairs, particularly in Izmir, which had by that time become the most important trading place for the Dutch. ${ }^{57}$ In 1671 , the States General ordered the Directorate of Levant Trade in Amsterdam to draft a new 'instruction' (instructie) that would fulfil these two goals. On 8 December 1673, a draft proposal was sent by the Directorate of Levant Trade in Amsterdam to the States General, which promptly expedited it to Consul Jacob van Dam in Izmir and Ambassador Justinus Colyer in Istanbul for comments. ${ }^{58}$

The version of the proposal included in Heeringa's Levantschen Handel was annotated by Consul van Dam, who sent a document with his comments back to the United Provinces in November 1674 and again in May $1675 .{ }^{59}$ Although the instruction itself never became law, as the authorities decided to focus on the matter of consular income and tax fraud, the document containing the proposal as well as the consul's remarks is historically important because it is the most extensive text in which the authorities discuss legal procedures for Dutch consular jurisdiction in the Levant. They not only provide insight into the thought process of some of the actors behind Dutch consular adjudication in the Levant but also contain several procedures that were applied in litigation in the United Provinces and that must have been equally applied by the consul in his office as judge.

The draft contained twenty-three articles, and many of them, articles 9 and 12 to 19, addressed adjudicating procedures in great detail. Article 9 confirmed the existing arrangement of assessors, who had to assist the consul in judicial and political affairs. The local Dutch community was to nominate six persons, out of whom the consul would choose three men to be appointed as assessors for two years. In case they were personally involved in a legal dispute, the

57 W.E. van Dam van Isselt, 'Het ontwerp-regeeringsreglement voor de Levant van 1673 en het formulier van 1675', in Bijdragen voor vaderlandsche geschiedenis en oudheidkunde, ed. P.J. Blok, 4th series, part 6 (The Hague, 1907), pp. 379-429.

$5^{8}$ Ibid., pp. 387-39o.

59 Heeringa and Nanninga, Bronnen tot de geschiedenis, 2: pp. 187-204, 'Reglement voor den resident tot Constantinopelen, consul tot Smirna, ende Nederlantsche natie in de Levant residerende respective, sooals hetselve bij de heeren Directeuren van den Levantschen handel aen H.H.M. is overgegeven, en bij deselve weder aen den Consul van Dam gesonden', 1675 . 
consul had to choose replacements amongst the other nominees or arrange for another round of nominations. As stipulated in earlier regulations, in case the whole local community was involved, temporary assessors would have to be chosen amongst the other Christian nations. Article 14 additionally stated that the assessors, when declaring not to be involved in the case they assisted to adjudicate, had to be believed at their word. Van Dam protested against this procedure to nominate assessors, and he argued that his problematic dealings with the trading community demonstrated that he should have absolute control over the nomination process. Furthermore, he felt that in all affairs he had to settle with the help of assessors, his voice should count double and would be decisive. Otherwise, he thought, the assessors could easily conspire against him. In the consul's opinion there was nothing in the draft that prevented partial judgment, as the assessors, who were merchants, could be motivated to judge on the basis of jealousy and their own commercial interests. The consul remarked that he had experience with many cases and that the merchants 'always advise according to their passions', while he was always without interest, as he was not allowed to engage in commerce himself. ${ }^{60}$

Article 12 stressed that, in order to avoid potential complaints on nonneutral sentencing, it was important to have clear regulations, which were explained in the articles that followed. It further stipulated that the consul and resident held the highest authority in their jurisdictions. Article 13 determined that, in case of a dispute, the consul and resident first had to try to settle matters amicably or have it referred to arbitrators, or 'good men of the nation'.61 Adjudication was to follow only in the case that arbitration failed, and it should be brief, without hesitation, and rapid, without lengthy procedures. ${ }^{62}$ Article 14 stipulated that the consul and assessors could adjudicate in cases up to 100 lion dollars, without the possibility of appeal before the ambassador in Istanbul. Cases involving an amount higher than 100 lion dollars or arising out of 'infamy or delict' could be appealed in Istanbul. ${ }^{63}$ The party that was condemned received a maximum of three summations to obey the verdict, with a risk of confiscation of goods should the verdict not be respected within

\footnotetext{
6o Ibid., p. 194, '[...] maer altijd naer hare passie adviseren $[\ldots . .$.

61 Ibid., p. 197, '[...] goede mannen van de natie [...]'

62 For arbitration, see pp. 131-132 and $138-152$.

63 Heeringa and Nanninga, Bronnen tot de geschiedenis, 2: pp. 187-204, 'Reglement voor den resident tot Constantinopelen, consul tot Smirna, ende Nederlantsche natie in de Levant residerende respective, sooals hetselve bij de heeren Directeuren van den Levantschen handel aen H.H.M. is overgegeven, en bij deselve weder aen den consul van Dam gesonden', 1675 , on p. 197, '[...] infamie of delict [...]'.
} 
fourteen days after the final summation. The consul agreed but demanded to be allowed to adjudicate without the assistance of the assessors in cases of 100 lion dollars or more. He also wished to be able to judge those who committed a crime against the consul himself - clearly in the hopes of establishing his authority more directly. ${ }^{64}$

Article 15 provided the consul with an extra vote in case the votes between him and the three assessors stalled. It also introduced the idea of weekly meetings, with fines for those who failed to attend. The consul repeated that he wished his extra vote to be permanent and dismissed the idea of weekly meetings, involving the whole nation, to discuss legal cases. Article 16 established fines for litigating parties not appearing at the court when due, which were half a lion dollar the first time and one lion dollar the second time. The third time, the case would be judged on the evidence brought forward by the plaintiff, unless the defendant had not been informed of everything in due time. Article 17 held that the consul and assessors had to pronounce their verdict within fourteen days after all the evidence had been presented, which was confirmed and further explained in article 19. As long as the sentence had not been issued, the party's demands to be heard by the court were to be allowed, but only if it could be demonstrated they had not been heard earlier because of the court's negligence. ${ }^{65}$

Article 18 dealt with the possibility of appeal against a consular verdict before the Dutch ambassador in Istanbul. The appeal itself had to be registered in the chancery in Izmir within ten days. If the appeal was for a case involving Dutch and non-Dutch merchants - disregarding whether they were European or Ottoman - the condemned party would have to put a deposit in the consular chancery, as negotiated between parties or as ordered by the consul and assessors. In addition, the person who demanded the appeal had to deposit twenty lion dollars, of which he would be reimbursed two-thirds in the case of the alteration of the verdict. Should the verdict remain the same, the money was forfeited. The ambassador was only allowed to adjudicate the appeal after the chancellor had confirmed the payment of all necessary sums. Article 18 further contained a very interesting specification on the citation of Ottomans. In case an Ottoman appeared before the consul and assessors, he had to declare in front of witnesses that he was willing to obey the verdict and would not seek appeal at an Ottoman court. Article 20 specified the financial

$\begin{array}{ll}64 & \text { Ibid., pp. 196-198. } \\ 65 & \text { Ibid., pp. 198-199. }\end{array}$ 
compensation the chancellor was to receive for all actions undertaken by him necessary for legal procedures. ${ }^{66}$

The proposed regulation was an impressive document and the most extensive written document dealing explicitly with legal procedures in the Levant. Some of the arrangements in the text had already been mentioned in the 1658 regulation, while others must have been an attempt to codify already existing procedures. Unfortunately, the implementation of these (or other seventeenth-century) rules dealing specifically with adjudication in the Levant and their concrete procedures cannot be tested by analysing concrete court cases that occurred at the same time, as no cases have been preserved for the period before $173^{2}$ (Istanbul) or 1743 (Izmir). There are no further indications that the draft proposal from 1673 was adopted. Instead, Dutch authorities concentrated their efforts on determining a fixed salary for the ambassador, consul and other officials attached to the embassy and consulates in the hopes of putting all disagreements between merchants and their representatives to rest. The States General had already issued regulations dealing with this matter in April and October $1675 .{ }^{67}$ The lengthy proposal on adjudication was lost in the discussion. In December 1679, the regulation for the consul, ambassador and other officials was renewed but contained no specific articles on consular or ambassadorial adjudication. The legal task of consuls and ambassadors remained codified on the basis of the regulation issued on 24 July 1658 and was only replaced in October $1791 .{ }^{68}$

While the legislation introduced in 1675 had not addressed any matters on adjudication, it did introduce one novelty that was tangentially related to the competence of the consulate as a court. It finally laid down a procedure for taking the Dutch national oath. ${ }^{69}$ All Dutch subjects, diplomatic personnel and merchants alike, had to swear to comply with regulations regarding the payment of tax duties on merchandise and to promise they would avoid all fraud. In an additional oath, the assessors had to pronounce that 'in all research, advice and adjudicating matters that shall happen, we shall behave

66 Ibid., pp. 199-200.

67 See pp. $45^{-46 .}$

68 Van Dam van Isselt, 'Het ontwerp-regeeringsreglement', pp. 405-406. For the 1679 resolution, see Heeringa and Nanninga, Bronnen tot de geschiedenis, 2: pp. 234-236, 'Resolutie van de Staten-Generaal betreffende den Consul van Dam en het reglement voor de Levant', 14/12/1679.

69 Cau, Groot placaet-boeck, 3: p. 311, 'Extract uyt de resolutien van de Staten Generael der Vereenighde Nederlanden; Reglement voor den resident tot Constantinopelen, consul tot Smirna, ende Nederlantsche natie in de Levant', o7/10/1675. 
ourselves neutrally, sincerely and loyally, as permitted as pious judges and assessors. ${ }^{70}$ The official inclusion of oaths was very important, as it was a formal subjection of the merchants to the jurisdiction of the consuls and ambassadors. Breaking an oath was an infraction that could be used against traders in court. ${ }^{71}$

The inclusion of an article forcing traders to take the Dutch national oath was an attempt to solve an old controversy. Consul van Dam had complained that, although the taking of an oath was obligatory for all merchants in the Levant since 1615 , as decreed by the States General, many of them refused to take it, something the consul believed had to do with the high level of fraud. Van Dam pointed out that the introduction of a national oath had worked well in battling fraud within the English trading community of Izmir, and Dutch subjects should equally be forced to take one. ${ }^{72}$ It remained a matter of dispute even after the 1675 regulation. Although W.E. van Dam van Isselt, one of the few historians who has written on the matter, asserted that the last Dutch merchant in Izmir who refused to take the oath did so in 1680, further States General legislation makes it clear that this was not the case. In 1687, thirteen merchants in Izmir still refused to take the oath in spite of the mediating efforts made by the consul's secretary, at the time Daniel Jean de Hochepied, and the Dutch ambassador in Istanbul. The merchants repeated older complaints about van Dam's inability to administer decent justice, a complaint apparently shared by the assessors, who wanted to be discharged from their office. ${ }^{73}$ In spite of these complaints, no further efforts were made to compile a general regulation for

$70 \quad$ Heeringa and Nanninga, Bronnen tot de geschiedenis, 2: pp. 208-217, 'Formulier, waernaer ende volgens hetwelcke den heer resident tot Constantinopelen, consul tot Smirna, aengestelt bij de H.M. heeren Staten-Generael der Vereenigde Nederlanden, en de gantsche Nederlantsche natie in de Levant residerende, respective, haer sullen hebben te reguleren omtrent den ontfanck en distributie van de ambassaet- en consulaetrechten', 1676 , on p. 213, '[...] soo belooven en sweeren wij mits desen, dat in 't ondersoeken, adviseeren en sententiëren van alle saeken, die sullen voorcomen, ons altos sullen dragen onpartijdich, oprecht en getrouw, als vroome rechters en assessoren toestaet [...]'.

71 See also pp. 133-135.

72 W.E. van Dam van Isselt, "Het "in train brengen" van het in 1675 voor de Levant ontworpen formulier (1675-1680)', in Bijdragen voor vaderlandsche geschiedenis en oudheidkunde, ed. P.J. Blok, 4th series, part 7 (The Hague, 1909), pp. 289-333.

73 Jacobus Scheltus, Groot placaet-boeck vervattende de placaten, ordonnantien ende edicten vande doorluchtige, hoogh mog: heeren Staten Generael der Vereenighde Nederlanden ende vande ed: groot mog: heeren Staten van Hollandt ende West-Vrieslandt mitsgaders vande ed: mog: heeren Staten van Zeelandt (The Hague, 1705), 4: pp. 248-249, 'Resolutie van haer hoogh mog., tot voorkominge en weghneminge van de onlusten tot Smyrna, onder de koopluyden van de Nederlandtsche natie aldaer ontstaen', 11/08/1687. 
adjudication, but dissenting merchants were forced to comply with the oath, on penalty of persecution and a hefty fine. ${ }^{74}$

In spite of this initial resistance, it became standard practice for newcomers to take the oath - without it, one was not able to participate in economic life in the Dutch Levantine trading communities. The consuls and ambassadors used the oath as an instrument to keep their subjects in line. When Dutch trader Isaac Beaune, upon arrival in Izmir in the 1760 os, wanted to associate himself with an Armenian trader, something which was forbidden, he was not allowed to take the Dutch national oath unless he was willing to give up his partnership. ${ }^{75}$ The problem of collecting consular duties was also dragging on. In 1683, the treasurer and assessors in Izmir informed the Directorate of Levant Trade that they finally had settled all accounts with van Dam on all financial matters. Nevertheless, when van Dam arrived back in the United Provinces in 169o, after he had been honourable discharged as consul, he still demanded reimbursement for various old expenses, reigniting long-standing animosities. ${ }^{76}$ Finally, the end of van Dam's tenure put a halt to more than half a century of disputes between Dutch diplomats and merchants. Van Dam was succeeded by his secretary Daniel Jean de Hochepied, who never antagonised his subjects as van Dam had done and who founded a consular dynasty, as the Izmir consulate remained in the hands of the de Hochepied family until 1824 .

In spite of the efforts made in the early 1670 , no extensive legal document ever came into being that fully settled the issue of adjudication by consuls and ambassadors. The adjudicating powers of consul and assessors were never questioned after the complaints lodged against van Dam. The States General might have felt that the most important matter was the establishment of consular and ambassadorial authority over their respective trading communities, and it was best ensured through regulations on taxes and the national oath. Authority as judge would then automatically follow, as the complaints on adjudication had been personal and were never aimed against the idea of consular adjudication itself. In addition, the national oath did include a promise to respect consular and ambassadorial jurisdiction and adjudication. Another

74 Ibid. Also in the same volume, see pp. 249-25o, 'Resolutie van haer hoogh mog., regulerende de ambassaet- en consulaet-rechten tot Smyrna en Constantinopolen', 22/o1/1688, and pp. 250-251, 'Resolutie van haer hoogh mog., noopende het vernieuwen van den eedt by den Levantschen handel, verhooging van ambassaet en consulaet-rechten tot Smyrna, Constantinopolen, \&c.', 30/07/1692, which seems to have been the last legislation that was issued on the matter.

75 See pp. $288-289$.

76 Van Dam van Isselt, 'Het "in train brengen". 
reason why the States General never issued further regulations detailing legal procedures at the consular courts might be that the authorities in the United Provinces felt existing legislation was clear enough regarding the practice of litigation, or in any case, it did not need additional rules that applied specifically to adjudication in the Levant. The jurisdiction and the consuls' abilities to adjudicate were codified in Dutch and Ottoman laws - through the capitulations - and that might have been a sufficient basis for consuls to adjudicate according to the same principles as those used by their peers adjudicating commercial disputes in the United Provinces. There was, however, one exception. In 1686, the States General published a law dealing with sequesters and appeals in the Levant. It would be the last time a law on legal procedure in the Levant was issued, and much like the failed 1673 attempt, it followed a draft proposal issued by the Directorate of Levant Trade. ${ }^{77}$

Analysing the processes behind the drafting of the seventeenth-century resolutions concerned with consular adjudication in the Levant is important in order to understand the nature of Dutch lawmaking in the early modern period. A first observation is that Dutch legislative institutions acted only in response to concrete problems. The regulations of 1616 and 1658 and the proposal of 1673 all had been drafted as legal answers to practical problems and were examples of the a posteriori making of regulations that was so characteristic of the legal framework the Dutch developed around their Levantine communities. The absence of a comprehensive body of Dutch laws and regulations dealing with Dutch consular adjudication in the Levant can largely be explained by the fact that the Dutch consul was almost exclusively dealing with commercial disputes, and the adjudication of these was done according to a specific, widely used procedure, 'summary procedure', that aimed at a fast and cheap resolution of disputes between traders. ${ }^{78}$ Naturally, summary procedure did not solve the issue of determining the legality of certain actions, such as a sequester in an international context, nor did it clarify automatically which court was competent to adjudicate a case, in first instance as well as in an appeal. Competence was generally solved by applying the custom of forum $r e i$, but use of this principle could still be rendered difficult in cases where litigants were physically far removed from one another - or from the court against which decision a losing party wanted to appeal. It was to address these matters that Dutch legislation applicable to the consulates in the Levant had come into being throughout the seventeenth century.

77 The law is discussed on pp. $265^{-267 .}$

78 Summary procedure is discussed in detail on pp. 119-138. 
The 1688 appointment of Daniel Jean de Hochepied as Dutch consul in Izmir not only put an end to all conflict between the consul and his subjects, it also concluded the period during which legislation was drafted and issued on consular adjudication in the Levant. In theory, this is easy to explain; the capitulations granted the Dutch full legal autonomy, which they could then exercise by applying the regulations concerned with commercial disputes that existed in the United Provinces. After all, the different Dutch Levantine communities remained, thanks to the principles of legal autonomy and consular jurisdiction, fully Dutch.

Two problems remained. First of all, a normal application of Dutch laws abroad only worked in cases where all the litigating parties were Dutch, or at least willing to submit to Dutch adjudication. The actual number of cases brought before the Dutch consul in Izmir in which all litigants were Dutch was very limited. Foreign involvement, particularly of Ottoman merchants, in Dutch trading operations was high, and the Dutch consul also held legal authority over a significant number of non-Dutch subjects, such as the Ottoman protégés. Although certain informal arrangements existed, such as forum rei or the early seventeenth-century acceptance of Ottoman traders to be tried at Dutch courts, the Dutch consular courts in the Levant were still vulnerable to outside challenges to their jurisdiction and competence - particularly when Ottomans were involved, as Europeans generally did not like to be subjected to Ottoman adjudication.

The second problem is perhaps more fundamental. There was no such thing as 'Dutch' law - just as there was no 'Dutch' political nation. ${ }^{79}$ The legal landscape of the United Provinces was a complicated web of local laws, rights and privileges next to provincial and 'national' legislation. Laws on sequesters, for instance, existed in the United Provinces to specify the cases when sequesters were legal and where they needed to be registered. Often, this was in the place where the goods were at that moment, but it could also be, depending

79 At least not in the sense of a unified, highly centralized state - the United Provinces was fundamentally different from monarchic states of the period for several reasons, but particularly for its highly decentralized political process, and the fundamental autonomy of its provinces. See Prak, The Dutch Republic in the seventeenth century, pp. 166-185. Often, 'Dutch' has been used as a synonym for 'from Holland'. While it is true that the province of Holland was the most powerful and the richest, and its inhabitants the most present in international trade, the 'Dutch' trading nation in the Levant was not simply the Holland trading nation. It seems important to stress that, during the early modern Dutch Republic, a sense of belonging seem mostly to have originated out of belonging to 'a family, neighborhood, club, guild, profession, church, city [...]'. Christine Kooi, Calvinists and Catholics during Holland's golden age: Heretics and idolaters (Cambridge, 2012), p. 41. 
on local custom, in the place of the plaintiff in cases where the defendant was in town. A number of restrictions existed and were defined in terms of privileges obtained by cities, such as the regulation that inhabitants of the bigger cities of Holland could not be subjected to a sequester of their goods in the countryside, unless they had been used as collateral. ${ }^{80}$ It is easy to see that it would be difficult to transfer existing legislation on sequesters in the United Provinces to the Levantine context, and this is one of the reasons why a specific law on sequester was published for the Levant. It shows that the situation on the ground could be too complicated to be handled fully by the existing body of written law, which makes it remarkable that so little effort was made to complement this existing body with new laws that would be able to cover the situation on the ground better. It is, however, less remarkable than it seems at first sight. By far, most disputes adjudicated by the consul of Izmir were commercial in kind.

Their adjudication was not conducted on the basis of written law, not even in the United Provinces itself, but on the basis of something else. That 'something else' needed to be flexible enough to be applicable in an international and intercultural context and practical enough to ensure swift resolution of disputes. That 'something else' did indeed exist and was called the merchants' style - the way in which merchants were accustomed to do things. It underpinned the business correspondences merchants maintained with one another, it was embedded in the substance of the contracts they signed with each other, and it was part of the oral agreements they mutually agreed upon. All of these expressions of the merchants' style could be used in court, and the great success of international commercial litigation can be attributed to the manner in which the early modern legal and commercial contexts offered the necessary space to incorporate this merchants' style into the legal framework that was used in adjudicating commercial disputes. In the case of the United Provinces that legal framework was built upon a variety of foundations but nonetheless merits, according to most early modern scholars, the label 'Roman-Dutch law'.

8o For a summary of the established body of law and the procedure of how to deal with sequesters in the United Provinces, see Cornelis Willem Decker, Het Roomsch Hollandsch recht; beschreeven door Mr. Simon van Leeuwen (Amsterdam, 1783), 2: pp. 361-371. Cornelis Decker was an attorney and notary from Amsterdam. A.J. van der Aa, Biographisch woordenboek der Nederlanden (Haarlem, 1858), 4: p. 78. Simon van Leeuwen (1626-1682) was an attorney at the Hof van Holland and Hoge Raad and a member of the town council in Leiden. He published several influential works on Dutch law, some of which will be discussed in more detail on pp. 120-122. Nieuw Nederlandsch biografisch woordenboek, eds. P.C. Molhuysen and P.J. Blok (Leiden, 1911), 1: pp. 1261-1263. 


\subsection{Sources of Roman-Dutch Law}

'Premodern Europe was a patchwork of local and regional jurisdictions, each with its own legal traditions. ${ }^{81}$ This is a generally accepted statement amongst legal historians, and a historiographical tradition that has been particularly strong in Germany has turned this observation into the idea that a shared European law, based on a mixture of Roman and canonical law called ius commune, was residual and subordinate to local laws that had taken form in statutes, consuetudines, local customary laws and other expressions of 'proper law', also called ius proprium. ${ }^{82}$ It seems clear now though that ius commune, as it developed after the fall of the Roman Empire and before the arrival of the Reformation in Christian Europe, 'created a shared legal tradition and a shared legal vocabulary that was more present in Europe than hitherto has been assumed and that influenced the "ius proprium" in such a way that it deserves a more formative position in the historiography of Europe's legal developments. ${ }^{83}$ The early Middle Ages was the formative period for this evolution, which took place in continental Europe and England in a parallel manner. In spite of later divergences and exaggerated claims regarding English exceptionalism, the English and continental European legal traditions are 'siblings' ${ }^{84}$ Ius commune relied strongly on Roman law but also was the result of an effort to overcome premodern Europe's legal patchwork, and it is hardly surprising that the post-Roman claim about a European 'common law' came from the church. Canonical law exerted a great influence on the European legal tradition. ${ }^{85}$

81 Gelderblom, Cities of commerce, p. 102; see also the collection of essays in Stephen Cummins and Laura Kounine, eds., Cultures of conflict resolution in early modern Europe (Farnham, 2016); and Dave De ruysscher, Gedisciplineerde vrijheid. Een geschiedenis van het handels- en economisch recht (Antwerp and Apeldoorn, 2014).

82 Emanuel G.D. van Dongen, Contributory negligence. A historical and comparative study (Leiden and Boston, 2014), pp. 227-228; and Manlio Bellomo, The common legal past of Europe 1000-1800 (Washington DC, 1995), pp. 55-77.

83 This common 'legal culture' would disappear in the later stages of the early modern period due to 'national' projects of legal codification. See Bellomo, The common legal past of Europe, pp. 1-33; see also Peter Stein, Roman law in European history (Cambridge, 1999); and Randall Lesaffer, Inleiding tot de Europese rechtsgeschiedenis (Leuven, 2008), particularly pp. 306-331 and 399-432.

84 Tamar Herzog, A short history of European law: The last two and a half millennia (Cambridge, MA and London, 2018), p. 115. For an overview of the early development of this ius commune and the shared history of continental European law and early English common law, see ibid., pp. 45-115.

Ibid., pp. 45-72. 
Roman law 'supplied the backbone for a common European legal tradition, [but] it could not solve the constant tensions between local and global, individual solutions and overreaching principles'. ${ }^{86}$

Later ideas about ius commune were of course influenced by the tendencies of nineteenth-century scholars to interpret European legal history as an evolution that led to the establishment of various sovereign 'national' legal systems. They might all have been related to each other, but more importantly, they were all considered fundamentally distinct from one another. The 'nationalist' lens through which historical developments are often distorted needs to be carefully adjusted, without immediately rejecting all efforts that were made to analyse the histories behind 'national' legal systems. The Dutch context is particularly interesting in this regard. In the early modern period, there was no codified 'national Dutch' legal corpus that was written down. The Netherlands has a civil law tradition, and Dutch law (ius patrium) was only codified in 1811, but this does not mean that any attempt to describe 'Dutch' law for the early modern period is useless. ${ }^{87}$ The first attempt to fully describe 'Dutch' law was made by Hugo de Groot, or Grotius, in 1631 (see figure 5). ${ }^{88}$ Several other early modern thinkers followed suit, and it was Simon van Leeuwen, an important Dutch legal scholar who invented the term 'Roman-Dutch law' (RoomschHollandts reght) to describe the totality of the rule of law in the early modern United Provinces, which was Dutch but firmly rooted in the tradition of Roman law. ${ }^{89}$

In his treatise on Dutch law, Laurens Pieter van de Spiegel (1737-180o), who later became the last grand pensionary of Holland, distinguished five different origins for the totality of law in the United Provinces (ius proprium or ius patrium): old custom, which only became law because it had been in use for so long; old local laws (keuren) and privileges (handtvesten) issued by the counts of Holland; the laws of the highest central governments after independence, for van de Spiegel the States General and the prince of Orange; Roman law; and lastly, canonical law. For van de Spiegel, a number of laws existed that could not be categorised in any of the five categories mentioned above, and he specifically mentioned exchange law and the customs of Dutch commercial

86 Ibid., p. 7 .

87 For an overview of the early modern sources of ius patrium, see Beatrix Jacobs, 'Ius patrium en ius commune. Twee zijden van een medaille', Pro memorie: Bijdragen tot de rechtsgeschiedenis der Nederlanden, 19:1 (2017): pp. 22-46.

88 Hugo de Groot, Inleiding tot de Hollandsche rechts-geleertheid (The Hague, 1631).

89 Simon van Leeuwen, Paratitula juris novissimi dat is een kort begrip van het RoomschHollandts reght (Leiden, 1652). 
cities as exceptions that he labelled somewhat disdainful as part of a 'multorum camelorum onus' - a burden of various camels. ${ }^{90}$

What these scholars shared was the acknowledgement that 'Dutch' law consisted of a vast body of local and regional laws, and van de Spiegel's division is similar to divisions scholars make today in the early modern sources for Dutch law. In her article on Dutch law, Beatrix Jacobs equally distinguished between privileges and custom. A third category was legislation, which is the same as van der Spiegel's category of 'laws of the highest governments'. Fourthly, Jacobs distinguished 'learned law' (geleerd recht), a category covering van der Spiegel's Roman and canonical law categories. Jacobs, different from van der Spiegel, included jurisprudence as a category, reflecting the growing practice of collecting and publishing the sentences of higher courts. Jacobs argues that these collections became important in setting examples but also acknowledges that the significance of this category as source of law remains up for debate. ${ }^{91}$

These sources refer to the totality of civil law and thus include commercial law. Even if the categorisation of sources of law as used by van der Spiegel in the eighteenth century, Jacobs in the twentieth and many others does provide a relatively clear analytical division of the origins of Dutch law, reality was considerably more complex - and no area of law perhaps more so as commercial law. By nature, the development of laws of trade contains an element of foreign interaction, because transactions over distance are inherent to the nature of trade. This observation is explicitly made in what is still the most comprehensive work on commercial law before the modern period. ${ }^{92}$ Its author, Wilhelm Franz Lichtenauer, did not categorise the origins of commercial law on the basis of theoretical labels, as Jacobs and van der Spiegel did. He was much more concerned with the places where commercial laws were written down. From the twelfth century onwards, the legal culture of the Low Countries increasingly became a written culture, leading to the growth of a written legal corpus. ${ }^{93}$ This development of written culture did not cancel the 'Dutch' legal fragmentation, but it must have enhanced the knowledge of local legal cultures in a wider area. Lichtenauer identified nine locations for finding written-down commercial law. The first coincides more or less with

90 Laurens Pieter van de Spiegel, Verhandeling over den oorsprong en de historie der vaderlandsche rechten, inzonderheid van Holland en Zeeland (Goes, 1769), pp. 113-114.

91 Jacobs, 'Ius patrium en ius commune', p. 38.

92 W.F. Lichtenauer, Geschiedenis van de wetenschap van het handelsrecht in Nederland tot 1809 (Amsterdam, 1968), p. 18.

93 Jacobs, 'Ius patrium en ius commune', p. 26; see also Wim van Anrooij, Handschriften als spiegel van de middeleeuwse tekstcultuur (Leiden, 2006), pp. 7-9. 


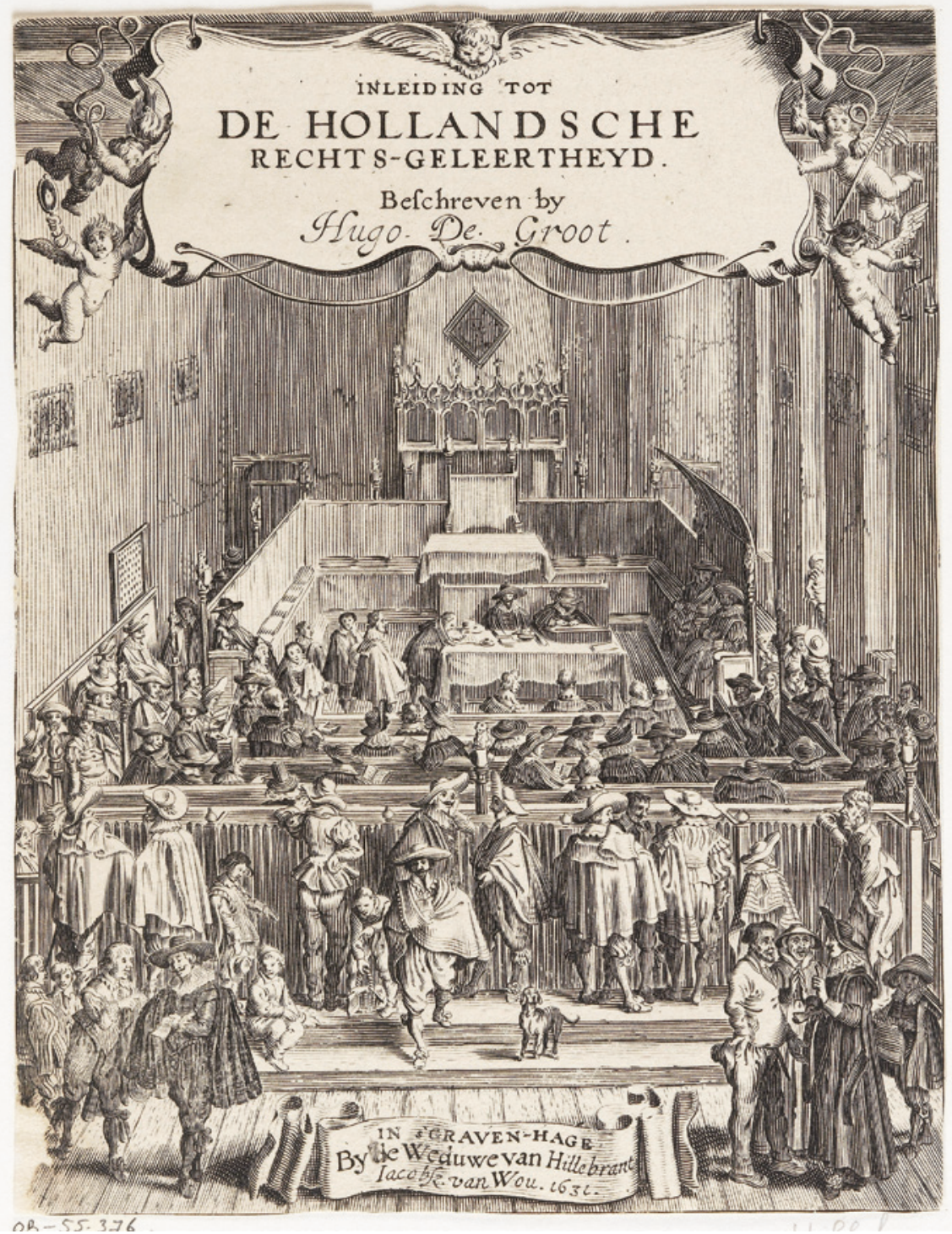

FIGURE 5 Image of the court room of the Hof van Holland from the title page of the first edition of Hugo de Groot's Inleiding tot de Hollandsche rechts-geleertheid, Gillis van Scheyndel (I), 1631

FROM THE COLLECTION OF THE RIJKSMUSEUM, AMSTERDAM 
'learned law' and consists of general publications by legal scholars, mainly discussing Roman law as well as other legal contexts where commercial legal stipulations can be found. Many are generalist and scientific, while some are moralistic - such as publications on bankruptcies. Two influential scholars publishing in the early modern period were Hugo de Groot in the seventeenth century and Cornelis van Bijnkershoek in the eighteenth century. Both wrote important works on the laws of Holland and Zeeland; de Groot's Inleiding tot de Hollandsche rechts-geleertheid (in English Introduction to the jurisprudence of Holland) was first published in 1631 (see figure 5), and Bijnkershoek wrote a Corpus iuris Hollandici et Zelandici, which was never published. ${ }^{94}$ De Groot, as others after him, extensively dealt with bottomry loans, the use of brokers, exchange law, sales, sea law, insurance, contract law and bankruptcy, and his work was much commented upon by later scholars. ${ }^{95}$ Next to scientific literature, Lichtenauer identified 'practical literature', such as manuals for notaries. In this category, he also included some well-known early modern monographs, such as Johannes Phoonsen's work on exchange law and Adriaen Verwer's work on maritime law. ${ }^{96}$

A third category is 'jurisprudence', under which Lichtenauer understood the instructions issued for specific commercial and maritime courts, such as the Commissioners of Maritime Affairs (Commissarissenvan Zeezaken), which was an urban maritime court established in several Dutch cities in the seventeenth century, as well as collections of sentences and legal advice. Specific collections on commercial and maritime law were only published at the end of the eighteenth century, the first being J.M. Barels' Opinions on commerce and maritime navigation. ${ }^{97}$ In the last decade of that century, an important collection

94 Lichtenauer, Geschiedenis van de wetenschap van het handelsrecht, p. 109.

95 Ibid., pp. 85-104.

96 Ibid., pp. 135-141. Johannes Phoonsen, Wissel-styl tot Amsterdam. Vervattende niet alleen het geene dat men gewoon, maar oock wat een voorsichtigh koopman, tot sijn securiteit, in de wissel-handel dienstigh en noodigh is, te observeren. Mitsgaders de ordonantien, willekeuren, en reglementen van wisselen tot Amsterdam, Rotterdam, Antwerpen, Hamburg/Franckfurt/ Leipzig/Nürnberg /Augspurg/Brewlauw/Bologna, Bisenzone, Bolzano, en Lions. Als oock de ordonnances de Louis XIV. sur le commerce de negotians \& marchands (Amsterdam, 1676); and Adriaen Verwer, Nederlants see-rechten; avaryen; en bodemeryen: begrepen in de gemeene costuimen vander see; de placcaten van Keiser Karel den Vijfden $155^{1}$ en Koning Filips den II 1563; 't tractaet van mr Quintyn Weitsen van de Nederlantsche avaryen: Ende daerenboven in eene verhandelinge nopende het recht der Hollantsche bodemeryen (Amsterdam, 1711).

97 J.M. Barels, Advysen over den koophandel en zeevaert. Mitsgaders verscheidene turbes, memorien, resolutien, missives enz. enz. daer toe behoorende, 2 vols. (Amsterdam, 1781). An early example of a collection that was not focussed on commerce is Consultatien, advysen 
of advice given by merchants on commercial disputes was published. ${ }^{98}$ This publication provided advice to the reader in the form of various turben (singular turbe). Turben were essentially expert declarations that were invoked to prove the existence of certain rules or customs and were first used in medieval France. They were crucial in determining the applicability of certain customs in court. ${ }^{99}$ In the Low Countries - they were used in Antwerp by the 1480 os declarations were registered in special books, turbeboeken, where they could be consulted later. ${ }^{100}$ Turben were crucial in determining the applicability of specific customs. Merchants were aware of the existence of published collections of opinions and expert declarations, and sometimes, they explicitly referred to them during litigation. ${ }^{101}$

In addition to these publications, Lichtenauer further mentioned alphabetical registry books, a number of orations and W. Hessen's 1776 publication of legal forms related to commerce as sources for written law, but he did not discuss them much. ${ }^{102}$ His last categories are laws - by which he meant the totality of written-down law in all its fragmented diversity; Hessen divided this category in local laws, regulations, ordnances, privileges, treaties, in which burghers of one city could count on certain privileges in another, and, lastly, custom and desuetudo. ${ }^{103}$

Lichtenauer made the crucial point that custom can be found in all of the other sources. For a good understanding of how the customs and usages of merchants found their way into court, it is important to realise that in certain environments, mercantile custom was incorporated into the law. The strong presence of foreign merchants in Antwerp contributed to the inclusion of merchant custom in local law; however, Dave De ruysscher has argued that the inclusion of custom and principles considered to be part of ius commune in the written corpus of Antwerp city law was primarily the work of aldermen

en advertissementen, gegeven ende geschreven bij verscheyde treffelijcke rechts-geleerden in Holland en elders, 6 vols. (Rotterdam, 1645-1666).

98 Verzameling van casuspositien, voorstellingen en declaratien, betrekkelyk tot voorvallende omstandigheden in den koophandel, van tyd tot tyd binnen deeze stad beoordeeld en ondertekend, 2 vols. (Amsterdam, 1793-1794).

99 L. Waelkens, 'L'origine de l'enquête par turbe', Tijdschrift voor rechtsgeschiedenis, 53 (1985): pp. 337-346.

100 Dave De ruysscher, 'From usages of merchants to default rules: Practices of trade, ius commune and urban law in early modern Antwerp',Journal of legal history, 33:1 (2012):pp.12-16.

101 For an example, see pp. 189-192.

102 Lichtenauer, Geschiedenis van de wetenschap van het handelsrecht, pp. 149-151.

103 Desuetudo is the abolition, never in writing, of older laws or customs. Lichtenauer, Geschiedenis van de wetenschap van het handelsrecht, pp. 151-154. 
and legal scholars. The absence of references to the 'customs of merchants' obscures the connection between custom and written law. De ruysscher concluded his analysis by stating that 'one may say that the City Court of Antwerp did not apply customs of merchants, but that the customs of merchants trading in Antwerp were the default rules imposed by the Antwerp City Court within a civil law framework'.104

There was certainly a tension between the application of merchant custom and local laws, or ius commune and ius proprium, in commercial litigation, and early modern legal scholars regularly underplayed the role played by merchant custom when writing their treatises, opting instead to focus on antecedents in Roman law. ${ }^{105}$ It has been argued that in certain circumstances, it was a cooperation between these two legal cultures that contributed to the development of a legal apparatus. It seems that in the sixteenth century, jurists in the Low Countries were able to use merchant custom and merge it with existing statutes, leading to new and improved maritime laws. ${ }^{106}$ De ruysscher's quote can also be considered as an expression of local city courts' efforts to retain their grasp over commercial litigation through ius proprium, rather than handing it over to forms of peer adjudication on the basis of ius commune. Such institutional competition was less of a problem in Izmir, where there was no local Dutch city court that might have challenged consular jurisdiction. ${ }^{107}$

The categorisation of the different sources for Dutch commercial law in the early modern period should not obscure the fact that there was a great deal of overlap and borrowing, not only through the insertion of custom into local laws but also through Roman legal principles that found their way into legislation. It should also not be forgotten that, while the law was made by local governments, and was in that sense an internal affair, it was influenced from the outside - and this is particularly relevant in the context of commercial and maritime law. A good example of these considerations is the history of the maritime ordinances issued by Charles V and Philip II in 1551 and 1563 respectively. These were ordinances that applied to all of the Burgundian Netherlands, as they were issued at a time when the Northern Netherlands were still part of the

\footnotetext{
104 De ruysscher, 'From usages of merchants to default rules', p. 29.

105 In the eighteenth century, for instance, Italian and German legal scholars were looking for the existence of credit contracts in Roman law. Francesca Trivellato, The promise and peril of credit. What a forgotten legend about Jews and finance tells us about the making of European commercial society (Princeton and Oxford, 2019), p. 113.

106 Dave De ruysscher 'Maxims, principles and legal change'.

107 There was, in some sense, competition from Ottoman courts, as merchants could choose to litigate before them, but it remained a choice rarely taken, and concrete competition was limited through the capitulations.
} 
Spanish Empire. While several of the articles in these ordinances went out of fashion, others were observed in the United Provinces even after Dutch independence. ${ }^{108} \mathrm{~A}$ good example is the practice of voering, private merchandise seamen could bring on the voyages on which they were employed, which was regulated by the maritime law issued by Philip II in 1563. The law stated that seamen could either bring private merchandise, to be put in the hold where the skipper indicated, or they could sell this right to the skipper who could then use the space to load more cargo. ${ }^{109}$ Commenting on the relevant article in 1711, Adriaen Verwer (c. 1655-1717) stated that this choice was no longer formally included in agreements between skippers and seamen. ${ }^{110}$

In 1665, a century after Philip II's maritime ordinance had been published, a legal scholar named Taco van Glins published a comment on the ordinance.111 In his address to the reader, van Glins evokes the men from the island of Rhodos, 'famous for their knowledge and experience in maritime navigation, and famous for their good sea laws and discipline on board'112 According to van Glins, Rhodian laws were so good that the Romans borrowed them, and Justinian acknowledged that his law on averages came directly from 'Rhodian law'. Van Glins continued to explain that the Rhodian example was followed by 'kings, princes and republics' and referred to famous old sea laws, such as the French Oléron laws and Scandinavian Wisby sea law, local regulations on maritime matters that were very influential in Europe. ${ }^{113}$ Van Glins then proceeded

108 While these attempts are testimony of a larger but failed effort at codification, they did create, in certain areas, some sort of cohesion over different jurisdictions. Boudewijn Sirks, 'Sources of commercial law in the Dutch Republic and Kingdom', in Understanding the sources of early modern and modern commercial law. Courts, statutes, contracts, and legal scholarship, eds. Heikki Pihlajamäki, Albrecht Cordes, Serge Dauchy, and Dave De ruysscher (Leiden and Boston, 2018), p. 172.

109 Adriaen Verwer, Nederlants see-rechten, p. 91. Reference is made to the origins of this stipulation in medieval maritime law.

110 Ibid., p. 95.

111 Taco van Glins, Aenmerckingen ende bedenckingen over de zee-rechten, uyt het placcaet van Koninck Philips uytgegeven den lesten octobris 1563. Alwaer der selver billickheyt uyt den gront van keyserlicke rechten, en krachtige beweeghreden bevestight, met andere zee-rechten over een gebracht, haer verschil aengewesen, en daer beneffens op verscheyden quaestien en voorvallen den koophandel en scheep-vaert aengaende, geantwoordt wordt. Den kooplieden en schipperen niet alleen, maer allen liefhebberen der rechts-geleertheydt seer dienstelick en profytelick (Amsterdam, 1665). On van Glins, see A.J. van der Aa, Biographisch woordenboek der Nederlanden (Haarlem, 1862), 7: pp. 210-211.

112 Van Glins, Aenmerckingen ende bedenckingen, n.p., 'die van Rhodus [...] eertydts in't bysonder vermaert van wegens haere groote kennisse en ervaerensheyt dewelcke ze hadden op de zeevaert, als mede van wegens haere goede zeerechten ende scheepstucht [...]'

113 Ibid., n.p., ‘[...] koningen, princen, en republiquen [...]'. For the mix of custom and legal codes in European maritime law, see the afterword by Maria Fusaro in Fusaro et al., eds., 
to discuss the articles of the maritime ordinances of Charles $\mathrm{V}$ and Phillip II, and he traced the origins of articles on freight charges, damaged cargo and other navigational issues back to older laws, particularly Wisby sea law. Van Glins' example is interesting because it demonstrates borrowing from other legal cultures, demonstrating concretely how foreign laws become incorporated in Dutch law. This can also be observed in legal compilations made of all relevant laws for cities in Holland. In 1639, for instance, a compilation of all laws relevant for the city of Amsterdam in terms of trade and maritime navigation was published in Dutch, with a title that translates as Charters or privileges, acts, custom and by-laws of the city of Amsterdam. ${ }^{114}$ These contained regulations taken from Wisby sea law, as well as from the Hanseatic cities, the ordinances of Charles v and Phillip II, charters of the counts of Holland, local by-laws from the city of Amsterdam and the rights and customs of the city of Antwerp, as well as other sources. ${ }^{115}$ Scholars have acknowledged that there was a transfer of legal customs between cities, transfers facilitated by the migration of merchants. ${ }^{116}$ In the case of Amsterdam, this can be related to the arrival of merchants from the Spanish Netherlands, Antwerp in particular, during the Dutch Revolt, but it also has to do with the nature of trade and the presence of foreign merchant communities. ${ }^{117}$

While it goes beyond the scope of this study to provide a detailed overview of the history of the origins of Dutch laws on commerce, it is important to note

Labour, law, and empire, pp. 304-310. For hybrid publications of local maritime law in the Spanish Netherlands before the revolt and their origins in legal texts from Scandinavia (Wisby), the Rôles d'Oléron and the Hanseatic towns, see Edda Frankot, 'Of laws of ships and shipmen' - Medieval maritime law and its practice in urban northern Europe (Edinburgh, 2012), pp. 14-26. A detailed comparison between two of the most important medieval maritime law codes can be found in Julia Schweitzer, Schiffer und Schiffsmann in den Rôles d'Oléron und im Llibre del Consolat de Mar - Ein Vergleich zweier mittelalterlicher Seerechtsquellen (Frankfurt am Main, 2006).

114 The full Dutch title is Handtvesten, ofte privilegien, handelingen, costumen, ende willekeuren der stadt Aemstelredam: Mitsgaders concept vande geraemde poincten op 't stuck vande iustitie, ofte maniere van procederen in civile saecken binnen deser stede: Met verscheyden placcaten dienstigh in diversche saecken. Als mede de zee ende scheeps-rechten van Wisbuy, vande oude Hanse steden, van Keyser Karel ende Koningh Philips: Met een tractaet van avarije. Alles verrijckt met een wijtloopig ende wel geordonneert register. Hier achter zijn by-gevoeght de rechten ende costumen van Antwerpen (Amsterdam, 1639).

115 Ibid., passim.

116 Dave De ruysscher, 'Antwerp commercial legislation in Amsterdam in the 17th century. Legal transplant or jumping board?' Tijdschrift voor rechtsgeschiedenis, 77 (2009): pp. 459-479.

117 For the migration of traders from Antwerp, see Oscar Gelderblom, Zuid-Nederlandse kooplieden en de opkomst van de Amsterdamse stapelmarkt (1578-1630) (Hilversum, 2000). 
that a great deal of the laws dealing with trade that found their way into written texts belonging to any of Lichtenauer's categories have their origins in old custom, and an important aspect of the commercial legal culture in the Low Countries was not just its fragmented nature but also its ability to incorporate foreign use and custom. It meant that merchants moving to a Dutch commercial city could, in certain instances, find a legal culture similar to the ones they had left behind in their places of origin. This familiarity not only applied to laws surrounding trade but can be somewhat extended to the courts themselves.It is not clear to what extent merchants were aware of the body of law within which the merchants' style that they did know was embedded, but by the eighteenth century, several notaries, attorneys and legal scholars had made compilations that contained useful information for traders. ${ }^{118}$ In at least one of the cases that will be analysed later, one of the litigants invoked both natural and civil law to substantiate her argument. ${ }^{119}$

\subsection{The Diversity of Jurisdictions and the Similarity of Courts}

While Manlio Bellomo argued for a larger, shared European legal context than was commonplace amongst historians, he did not deny the existence of legal fragmentation in itself, and it was an early modern reality that litigants were faced with a multitude of jurisdictions. This was largely due to the absence of strong and centralised modern nation-states that relied on an extensive corpus of written-down national laws. In the United Provinces, this situation was even more extreme than in many other early modern European states. The Dutch Republic was a strongly decentralised state with divided political power. Cities and provinces had their own governmental system and possessed a great deal of political autonomy. The provincial states, such as the States of Holland, were composed of representatives of the nobility and the cities, and there was an agreement to protect existing local privileges. More central governmental institutions did exist, most importantly the States General, but its jurisdiction was limited to foreign affairs. Its composition did not reflect the political and financial power structures of the Dutch Republic, as all provinces had one

118 A good example in Dutch is Arent Lybreghts, Burgerlyk, rechtsgeleerd, notariaal en koopmanshandboek; behelzende een korten grondslag van de rechtsgeleerdheid, notariaale practyq en van den koophandel zeer dienstig niet alleen voor advocaten, procureurs, solliciteurs, schouten en secretarissen ten platen lande, en practiseerende boekhouders; maar ook voor voogden, executeurs, administrateurs, en curateurs; die zich in den koophandel willen oeffenen, en voor yder burger van Nederlands gemeenebest, 4th ed. (Amsterdam, 1764). In English, there was for instance G. Jacob, Lex mercatoria: Or, the merchant's companion. Containing all the laws and statutes relating to merchandize (London, 1718).

119 See p. 246. 
vote, disregarding their real political and economic weight. ${ }^{120}$ The absence of a strong centralised state apparatus was an elementary characteristic of the Dutch Republic, which had come into being in a region that already carried a long medieval tradition of decentralised territories and had resisted, ultimately successfully, the Spanish effort of incorporation into a global empire. ${ }^{121}$

This political fragmentation had important consequences for litigation. When merchants went to court in the United Provinces, they went first and foremost to a local court. Oscar Gelderblom has argued that the three most important commercial cities in the Low Countries, Bruges, Antwerp and Amsterdam, 'developed more inclusive commercial regimes in which all merchants were treated equally and the commercial infrastructure served the merchant community at large.'122 This was part of a strategy aimed to keep foreign merchant communities in the city, without providing them with special status, and it included the development of legal instruments merchants could use to solve their disputes. ${ }^{123}$ This long development originated in the Southern Netherlands, where cities had developed at an earlier stage than in the north. In Flanders and Brabant, several urban courts had managed to extend their jurisdiction into the countryside. In Holland, the most important of the northern provinces, the situation was different. Urban and rural courts each had their own jurisdictions, and ecclesiastical courts continued to play an important role as well. Initially, this fragmentation seems to have hindered the expansion of trade. Jessica Dijkman, for instance, argued that in cases of debt litigation, creditors had to physically travel to the debtor's jurisdiction to claim their money there, a situation that differed from practice in England and the Southern Netherlands. ${ }^{124}$ It seems very plausible that the practical problems brought about by legal fragmentation contributed to the development of informal arrangements, which complemented the formal legal system, and these served as early and perhaps local examples of the merchants' style.

In the later Middle Ages, the growing power of the count of Holland changed the legal landscape of local and traditional forms of adjudication. By the end of the thirteenth century, Holland possessed a more centralised justice system,

\footnotetext{
120 De Vries and van der Woude, Nederland, p. 125.

121 For an overview of the Dutch political structures, see Prak, The Dutch Republic in the seventeenth century, pp. 166-185; see also Price, Holland and the Dutch Republic.

122 Gelderblom, Cities of commerce, p. 40.

123 For an extensive analysis of the development of conflict resolution mechanisms, see ibid., pp. 102-140.

124 Jessica Dijkman, Shaping medieval markets. The organisation of commodity markets in Holland, c. $1200-$ c. $145^{\circ}$ (Leiden and Boston, 2011), pp. 265-268.
} 
in which the count of Holland and a number of counsellors adjudicated certain disputes. This allowed for some important procedural innovations, such as clear instructions on the admittance of evidence. ${ }^{125}$ Attempts were made to streamline the different jurisdictions in Holland and to further centralise a number of disputes. Duke Willem of Bavaria (1365-1417), count of Holland and Zeeland, released an order stating that 'our sheriff and aldermen administer justice and declare sentences concerning all those who are seaworthy and fleet-worthy, and the same of all seaworthy goods. ${ }^{126}$ This clause specifically aimed to cover potential problems of jurisdiction concerning people whose regular displacements made them cross legal boundaries, such as merchants who were, at the time, often still itinerant.

The count's efforts brought more unity to the different formats of local traditions, but the most important Dutch institutional framework dealing with maritime and commercial disputes was developed within urban jurisdictions, where it was needed the most - although local laws were periodically upheld by Burgundian and Spanish affirmations of privileges. In 1413, Amsterdam's magistrates had issued a law stating that conflicts between foreigners were to be adjudicated by the aldermen's bench (the court of aldermen). ${ }^{127}$ Amsterdam organised the election and constitution of the council of citizens that ruled the city, the vroedschap, which included the aldermen and burgomasters coming from a number of elite urban families. Over time, regulations stipulated that out of the nine aldermen, several needed to be versed in commerce and maritime navigation. The reason given for this change was that the aldermen's bench had to adjudicate commercial disputes within its jurisdiction. ${ }^{128}$ On days on which the bench convened, the city's sheriff opened the session by addressing the president of the court personally, instructing him to administer the law and justice 'to the old customs and privileges of this city' ${ }^{129}$

Amsterdam continued to expand in the late sixteenth and seventeenth century, and the success of its legal institutions can perhaps be observed in the growing burden that litigation posed on the aldermen's bench, which was a general court that adjudicated all legal matters in Amsterdam. Contrary to

\footnotetext{
125 Ibid., p. 264.

126 Handtvesten, p. 20.

127 Gelderblom, Cities of commerce, p. 123.

128 Jan Wagenaar, Amsterdam in zyne opkomst, aanwas, geschiedenissen, voorregten, koophandel, gebouwen, kerkenstaat, schoolen, schutterye, gilden en regeeringe beschreeven door Jan Wagenaar historieschryver der stad (Amsterdam, 1768), 12: p. 17. Wagenaar (1709-1773) was a well-known Dutch chronicler and historian.

129 Ibid., p. 176, ‘[...] naar de oude coustumen en privilegien deezer stede’, a phrase pronounced by the sheriff.
} 
other commercial cities, such as Bruges and Antwerp, Amsterdam never admitted consular jurisdiction. ${ }^{130}$ After the Dutch Revolt, the foreign communities in Amsterdam were not only groups of merchants but also religious refugees. Even though no consular courts existed in Amsterdam, the city did allow for religious leaders of certain groups to administer justice to members of their religious communities. ${ }^{131}$ The leaders of the Portuguese Jewish community in Amsterdam, the parnassim, for instance, adjudicated a number of disputes between members of the community, and Amsterdam local courts could refer Jewish litigants to these leaders in order to reach an amicable settlement. ${ }^{132}$

In spite of the jurisdiction given to leaders of a number of religious communities, the city's legal institutions retained their primacy. It was perhaps out of this desire to control adjudication within the city that, from a very early moment onwards, Amsterdam's government considered the establishment of more specialised courts. As early as 1516, urban authorities had contemplated the foundation of a court aimed at settling disputes between merchants and seafarers, but it would take more than a century before such plans were finally realised. In the last decades of the sixteenth and the first half of the seventeenth century, more specialised civil courts were created to deal with specific types of disputes. A Chamber of Insolvent Estates (Desolate Boedelskamer) came into being in 1643, while the Bench of Minor Affairs (Bank van Kleine Zaken), established in 1611, took care of disputes limited to the sum of forty guilders, including those involving commerce. In 1650, the limit was raised to 600 guilders, which raised the number of cases to such an extent that cases related to violence were transferred to the Commissioners of Maritime Affairs (Commissarissen van Zeezaken). ${ }^{133}$ This court was founded in 1641 to adjudicate all disputes between merchant and skipper, skipper and skipper, merchant and seaman and skipper and seaman. ${ }^{134}$ Rotterdam, Middelburg and Vlissingen followed and established maritime courts of their own.

130 Gelderblom, Cities of commerce, pp. 121-123.

131 These communities could use social forms of punishment, such as exclusion from the group. Ibid., p. 122.

132 CAA, $\mathrm{N}^{\circ} 334$ ('Archief van de Portugees-Israëlietische Gemeente'), $\mathrm{N}^{\circ} \mathrm{s} 875^{-877}$ ('Livros de citaçoes e resoluçoes', 1717-1816). These volumes are registries of parties appearing before the parnassim. $\mathrm{N}^{\circ} \mathrm{s} 878-88$ o contain parnassim sentences in affairs that were referred to them by the Bench of Minor Affairs between 1710 and 1806 .

133 For the changes in the Bench of Minor Affairs during this period, see Hans Bontemantel, De regeeringe van Amsterdam, soo in 't civiel als crimineel en militaire (1653-1672), ed. G.W. Kernkamp (The Hague, 1897), 2: pp. 453-463.

134 Extract registers Amsterdam, 31/o1/1643. In England, this became the competence of the Admiralty Court. See George F. Steckley, 'Merchants and the Admiralty Court during the English Revolution', American journal of legal history, 22:2 (1978): pp. 137-175. 
The maritime court took care of commercial disputes if they were directly related to maritime navigation, but it was not a commercial court. It is remarkable that, contrary to other cities in Europe, no specific court was established in the United Provinces that exclusively adjudicated commercial disputes; these remained divided amongst different local courts. ${ }^{135}$ Johannes Phoonsen (1631-1702), who published a book on exchange law for merchants, argued that the establishment of a commercial court was highly necessary, and as he was convinced of the importance and centrality of bills of exchange in trade, he thought it best that the commissioners of the Amsterdam exchange bank were given legal authority as a court to adjudicate all commercial disputes involving bills of exchange and to extend it to deal with all trade disputes that were not explicitly the domain of the Commissioners of Maritime Affairs or the insurance chamber. ${ }^{136}$ While this suggestion was never implemented, it does show the continuing effort to address problems of attempting to institutionalise commercial adjudication.

Local courts - particularly urban aldermen courts - continued to adjudicate commercial disputes. Additionally, merchants could also seek recourse to a central court. These were only established after Holland had become part of the Burgundian state in the middle of the fifteenth century. In the province of Holland, there were the Hof van Holland (see figure 5) and the Hoge Raad, while the highest court of all the Burgundian Netherlands was the Grote Raad in Mechelen. ${ }^{137}$ The States General had some judicial authority, but its verdicts, subsequently turned into resolutions, were directly based on other courts' sentences. ${ }^{138}$

These centralised courts served as courts of appeal in commercial matters, but in the fifteenth century, the Burgundian rulers of the Low Countries offered foreign merchants the privilege to bring their disputes before these central courts first. It was a logical solution, as a more central court had a

\footnotetext{
135 See, for instance, Amalia Kessler's monograph on the Parisian merchant court, A revolution in commerce.

136 Phoonsen, Wissel-styl tot Amsterdam, pp. 235-236. 'Exchange law' was used by contemporaries to refer to regulations concerning bills of exchange.

137 For the Hof van Holland, see Marie-Charlotte Le Bailly, Procesgids Hof van Holland, Zeeland en West-Friesland (Hilversum, 2008); and Recht voor de Raad. Rechtspraak voor het Hof van Holland, Zeeland en West-Friesland in het midden van de vijftiende eeuw (Hilversum, 2001); for the Hoge Raad, see Marie-Charlotte Le Bailly and C.M.O. Verhas, Hoge Raad van Holland, Zeeland en West-Friesland (1582-1795) (Hilversum, 2006); see also Dijkman, Shaping medieval markets, p. 269.

138 N.M. Japikse and A. van der Poest Clement, Inventaris van het archief van de StatenGeneraal (1431) 1576-1796 (The Hague, 1969), p. 25.
} 
wider jurisdiction, meaning their verdicts could reach further - making them theoretically more apt to deal with trade. In spite of these efforts, local courts had no need to worry, as in the Low Countries, the central courts continued to only play a small role in the adjudication of commercial disputes, even when international trade was expanding. Oscar Gelderblom has shown that, for the fifteenth and sixteenth centuries, traders' recourse to the centralised courts of Flanders, Brabant, Holland and Zeeland was limited, which he attributed to the long timespan that was often needed to reach a verdict. ${ }^{139}$ They did play a role as appeal courts, and in this sense, the Hof van Holland and the Hoge Raad, the two large centralised courts of the Dutch Republic, are relevant to this study. In the first instance, traders continued to rely on urban courts, preferably specialised ones. Thanks to the consular system, Dutch traders abroad could rely on similar access to adjudication in the manner they were used to, much like their foreign colleagues residing in the Low Countries, who expected the same.

\section{Procedures in Commercial Litigation}

\subsection{Dutch Regulations on Procedure}

The development of specialised local courts taking care of specific disputes was important and led to the adjudication of commercial disputes in urban courts. Instructions for these courts, as well as instructions for the more centralised ones, clearly delineated jurisdictions. There was, however, no guarantee of unity in procedure, as local courts had adopted their own ways of administering justice over time. This diversity grew after a 1577 regulation stipulated that all towns and villages in the province of Holland had to have their own aldermen court. ${ }^{140}$ After 1572, the province of Holland was ruled by the States

139 Gelderblom, Cities of commerce, pp. 126-133. In spite of their relatively limited importance in commercial adjudication in relation to the urban courts, several scholars have looked into archival and handwritten material containing the notes and opinions of judges on sentences issued by the Hof van Holland and the Hoge Raad. See, for instance, H.C. Gall, Regtsgeleerde decisien. Aan de raadsheer Pieter Ockers toegeschreven aantekeningen betreffende uitspraken van het Hof (1656-1669) en de Hoge Raad (1669-1678) van Holland, Zeeland en West-Friesland (Amsterdam, 2002). While these notes do not focus on commerce, they do contain trade-related material. An extensive account of the legal context in which these courts operated in terms of trade disputes can be found in Christian Brom, Urteilsbegründungen im 'Hoge Raad van Holland, Zeeland en West-Friesland' am Beispiel des Kaufrechts im Zeitraum 1704-1787 (Frankfurt am Main, 2008).

140 J.L. van der Gouw, 'Costumen betreffende land liggende gemener voor', in Ter recognitie. Opstellen aangeboden aan Prof. Mr. H. van der Linden bij zijn afscheid als hoogleraar in de 
of Holland and Westfrisia, composed of eighteen representatives for the eighteen voting cities - which included Amsterdam, Leiden and Rotterdam - and the college of nobles, with one vote and which represented the countryside, as well as the cities with no vote of their own. ${ }^{141}$ The States of Holland decided in 1580 that there was 'a great deal of confusion and diversity of rights and special custom in legal claims, procedures, sentencing and execution of sentences'.142 They also noticed that there had been many complaints by the inhabitants of the province of Holland on the lack of a decent law regulating procedures. ${ }^{143} \mathrm{To}$ fill this lacuna, the States of Holland published an ordinance in 1580 that was to streamline civil procedure at all local courts in the province of Holland - the Ordinance dealing with justice, within the cities as well as on the countryside, in the year 1580 (Ordonnantie op 't stuk van de Justitie soo binnen de steden als ten platen Lande, in den jare 1580). ${ }^{144}$ It turned out to be the most important piece of legislation on procedure in Holland, but it was not the first one. Wagenaar mentioned the publication of a Burgundian ordinance rule as early as 1538 that aimed at shortening litigation. ${ }^{145}$

The 1580 ordinance was of crucial importance because its twenty-two articles laid out the procedural framework for civil law litigation, replacing 'all customs, uses and other styles [of administering justice] used so far that are contrary to this law and that are hereby derogated. ${ }^{146}$ Article 1 described the manner in which the plaintiff was to summon the defendant - with the crucial

Nederlandse rechtsgeschiedenis aan de Vrije Universiteit, eds. C. Streefkerk and S. Faber (Hilversum, 1987), p. 279.

141 See S.J. Fockema Andreae, De Nederlandse staat onder de Republiek, Koninklijke Nederlandse Akademie van Wetenschappen. Verhandelingen afd. Letterkunde. Nieuwe reeks, vol. 68, no. 3 (Amsterdam, 1978).

142 'Ordonnantie op 't stuk van de justitie, binnen de steeden ende ten platen landen van Holland, \& c., in Manier van procedeeren in civile en crimineele saaken, eds. Simon van Leeuwen, Henrik Verduyn, and Willem van Aller, 5th ed. (Amsterdam, 1721 [1666]), pp. 1112, on p. 1, '[...] seer groote confusie ende verscheydenheyd van regten, soo vermids haar luider bysondere coustumen in de regtvordering, procedeeren, in ' $t$ sententieeren, als ook in 't executeeren van de sententien [...]'.

143 Ibid., p. 2.

144 For legal procedures in criminal law, Phillip II had already issued a similar ordinance in 1570, the 'Ordonnantie, edict ende gebod van den jaare 1570 op 't stuk van de crimineele justitie in de Nederlanden', in Manier van procedeeren in civile en crimineele saaken, eds. Simon van Leeuwen et al., pp. 113-278. Both documents were collected and commented upon by the legal scholar Simon van Leeuwen and amplified later by lawyers and other scholars, with additional annotations.

145 Wagenaar, Amsterdam in zyne opkomst, 12: pp. 172-173. This volume was extended in 1656.

146 'Ordonnantie op 't stuk van de justitie', pp. 110-111, '[...] coustuymen, usantien ofte andere stylen tot nog toe contrarie desen gebruykt, die by desen werden gederogeert [...]' 
observation that it was to take place at the court under whose jurisdiction the defendant fell. ${ }^{147}$ Several of the articles thereafter dealt with the consequences of the nonappearance of either litigant - monetary fines for up to three nonappearances and ultimately sentencing. Article 10 codified the first proceedings when both parties physically appeared before court. The plaintiff had to bring his claim in writing, which had to be handed over to the secretary or clerk, who wrote it down. The plaintiff was allowed to claim a security deposit but could also wait to do that later during the trial. ${ }^{148}$

Article 11, which dealt with the distinction between written and oral procedure, was crucial. In court, the litigants had to reply to each other's arguments with their counter-arguments. This back-and-forth could be done in writing or by speaking directly in front of the judges. This article set the procedural choice between the two on the basis of the financial value of the claim; oral procedure applied for cases with claims under either 100 guilders (cities) or 50 guilders (villages). When oral procedure applied, written arguments were not allowed. A footnote stipulated that these were small affairs ('kleyne saaken') which were adjudicated in 'the summary manner'. ${ }^{149}$ Simon van Leeuwen, one of the legal scholars commenting on this law in a later publication, explained what that meant - fast adjudication. ${ }^{150}$ Lawyer Hendrik Verduyn, one of the other commenters, added a remark about the 1674 law from the States of Holland, which raised the monetary limit for the use of the 'summary manner' from 100 to 600 guilders in large cities, 300 in smaller cities (such as The Hague), and between 80 and 120 guilders in villages. ${ }^{151}$ Further explanations by these two scholars made it clear that judges kept minutes of what was said by the litigants, but the latter were not allowed to submit written statements. The competent judges heard the litigants' replies and counter-replies and sentenced the case. ${ }^{152}$

In 1783 , lawyer and notary Cornelis Decker edited a treatise on RomanDutch law originally written by Simon van Leeuwen. He commented in more detail on the nature of the oral procedure. First, he clarified it was indeed used for simple or pressing issues - cases that did not need further investigation or cases that could not be delayed. Decker added that the oral procedure was the most common legal procedure, used both in the cities and the countryside.

\footnotetext{
147 Ibid., pp. $5^{-14}$.

148 Ibid., pp. $35^{-53}$.

149 Ibid., p. 44.

150 Ibid., p. 45 .

151 This corresponded, of course, to the rising importance of fast litigation. See pp. 124-131.

152 'Ordonnantie op 't stuk van de justitie', p. 45. Both litigants were generally allowed to reply twice, but not more.
} 
It started with the plaintiff's narration of his claim and the reasoning behind it. This should be short. The defendant was then allowed to answer with his own version of events and refute the claim of the plaintiff. After that, it was the plaintiff's turn again to reply with a more in-depth argument in which he could refer to 'laws and doctors' and cite existing jurisprudence. This was officially called the reply (replyq), which was answered by a similar counter-reply (duplyq) from the defendant. ${ }^{153}$ In this system of back-and-forth replies and counter-replies, there were two rounds - the law specified that an additional round, of a third reply (triptycq) and counter-reply (quadruplycq), was forbidden. ${ }^{154}$ When the litigants had brought in all their arguments, the case was sentenced by the judges.

Cases that exceeded the financial limits for oral procedure were discussed in article 12. After the plaintiff made his claim, the defendant was given eight days to respond, either in writing or orally, in cases where a city court was concerned, and two weeks in cases where a village court was handling the case. According to van Leeuwen, the choice for submitting a written argument was based on the length of the answer. If the defendant's answer was too long to be written down by the clerk in the minutes of the court, it needed to be handed over in writing, in narrative form. After that, further replies and counter-replies could be presented orally if both litigating parties agreed to do so. ${ }^{155}$ This article clearly indicates that even for cases involving a larger financial claim, the law explicitly allowed for an oral procedure - but in this case, litigation could only proceed in this manner should both plaintiff and defendant agree.

Articles 11 and 12 established slightly different procedures for different cases based on the value of the plaintiff's claim, but the exact nature of the cases themselves was never discussed in the 1580 ordinance. Only one type of dispute was mentioned, in articles 15 and 16 , and that was a case that disputed facts ('saken in feyten') - this meant a witness was necessary in order to adjudicate. These needed to follow a different procedure, for the obvious reason that an additional party needed to be inscribed in the legal process - the witness. ${ }^{156}$

\footnotetext{
153 Decker, Het Roomsch Hollandsch recht, 2: pp. 548-550.

154 'Ordonnantien', p. 54. It seems, however, that it existed in certain situations and regions the law for Overijssel, the region around Zwolle and Kampen, for instance, specifies the use of 'triplycq' and 'quadruplycq' in disputes with a sufficiently high financial claim. Christoffer Nessink, Het landt-recht van Over-Yssel (Kampen, 1747), pp. 333-334.

155 'Ordonnantie op 't stuk van de justitie', pp. 46-47. There are several examples of the use of the 'triptycq' and 'quadruplycq' in cases brought before the Dutch consul in Izmir.

156 Ibid., pp. $55^{-70}$.
} 
Article 18 laid down rules on the admittance of copies in court - these needed to be compiled in a certain way and certified to be authentic. Article 21 stipulated the conditions to appeal a sentence, while article 23 determined that sentences needed to be executed within ten days if no appeal was made. ${ }^{157}$ This 1580 ordinance was crucial, as it was the first law that attempted to regulate procedure within the whole province of Holland and go beyond local custom. Although the phrasing is not entirely clear, it seems that this law was also applied in Zeeland and Frisia. ${ }^{158}$ Other provinces quickly followed suit. Utrecht issued its regulation on the system of civil legal procedures in 1583 and based it directly on the 158 o legislation. The States of Frisia issued a specific ordinance on legal procedures in $1602 .{ }^{159}$

All local courts within the jurisdiction covered by these laws had to abide by them. The central courts, such as the Hof van Holland, operated on the basis of their own separate sets of regulations. ${ }^{160}$ Local courts included the specialised courts in the cities, as well as those litigating commercial disputes, such as the Commissioners of Maritime Affairs in Amsterdam and Rotterdam. The instructions published at their establishment dealt with the competence of these courts, members and dates of sessions. They also specified specific infractions and their penalties - in the case of the Commissioners of Maritime Affairs these ranged from seamen disobeying their captains to quarrels between freighters and shipowners about the shipped goods. ${ }^{161}$ These instructions did not establish new procedures, as the courts had to follow the 1580 ordinance in terms of legal procedures. ${ }^{162}$ As specified in that ordinance, trials at the urban courts began - similar to those at the Hoge Raad and Hof van Holland - with a request for summoning made by the plaintiff. The defendant was placed on a rol, a registry containing the cases to appear before the aldermen. Originally, there were different registries for different types of cases, but with the arrival of more specialised courts these different registries disappeared. Contrary to the higher provincial courts, the defendant, or someone on his behalf, had to

\footnotetext{
157 Ibid., pp. 71-72 (article 18), 85-87 (article 21), and 90-91 (article 23).

$15^{8}$ Ibid., p. 2.

159 Rembt van Boneval Faure, Het Nederlandsche burgerlijk procesrecht (Leiden, 1893), 1: p. 33.

160 See pp. 271-272.

161 See pp. 117 and 124.

162 For the instructions of the maritime courts of Amsterdam and Rotterdam, see Extract keurboek Rotterdam, 16/03/1655 and Extract registers Amsterdam, 31/01/1643. The Amsterdam instructions were renewed in 1731 and 1774. Instructien en ordonnantien voor Commissarissen van Zee Zaken (Amsterdam, 1731); and Instructies en ordonnantien voor de Commissarissen van Zee Zaken (Amsterdam, 1774).
} 
appear in person. Then, the case was ready to be adjudicated following the legal procedures first set out in $1580 .{ }^{163}$

There were two reasons the oral procedure, set down in article 11 of the 1580 ordinance, took such a prominent place in litigation. Following the 'legal revolution' of the sixteenth century, litigation expanded enormously in various regions of Europe, and many people sought recourse to the court system which had to be able to adjudicate a multitude of small disputes between people who could not necessarily read or write. ${ }^{164}$ The oldest extant rol of the Commissioners of Maritime Affairs in Amsterdam contains more than 760 cases adjudicated between March and June $1641 .{ }^{165}$ Judges would never be able to process that many disputes if all the arguments had to be brought to the court in writing, particularly as written replies and counter-replies could not be fabricated on the spot. A second reason for the use of the oral procedure was that it could guarantee speedy sentencing. This was not only relevant in the context of the rise of litigation - which did not continue through the eighteenth century - but was particularly important in the expanding number of commercial disputes that were also of an increasingly international nature. Merchants preferred fast sentences, so neither their time nor their resources were caught up in a trial. This aspect was referred to by Simon van Leeuwen as a 'summary' procedure - fast and simple adjudication without the involvement of professionals such as lawyers. ${ }^{166}$

\subsection{Summary Procedure and the Merchants' Style}

Summary procedure was considered a privileged form of procedure, the use of which was granted by Italian states to the category of the misérables - people who were low on the social ladder and needed legal protection as well as cheap and fast judgment. These people not only included the poor, widows, minors,

163 For a complete overview of normal as well as exceptional procedures, see Wagenaar, Amsterdam in zyne opkomst, 12: pp. 172-199.

164 See footnote 30 on p. 90.

165 CAA, ${ }^{\circ}{ }_{5}{ }^{\circ} 61$ ('Archieven van de schout en schepenen, van de schepenen en van de subalterne rechtbanken'), $\mathrm{N}^{\circ} 2490$ ('Rol voor Commissarissen van de Zeezaken', 21/03/1641-07/o9/1641).

166 For van Leeuwen's definition of summary procedure, see 'Ordonnantie op 't stuk van de justitie', pp. 44-45. For an analysis of summary procedure, see Simona Cerutti, Giustizia sommaria. Pratiche e ideali di giustizia in una società di Ancien Régime (Torino XVIII secolo) (Milan, 2003); see also Mario Ascheri, Tribunali, giuristi e istituzioni dal Medioevo all'età moderna (Bologna, 1989), pp. 23-54; and Alessandro Lattes, 'Il procedimento sommario', in Il procedimento civile nella legislazione statutaria italiana, ed. Pietro Sella (Milan, 1927), pp. 216-267. 
orphans and pilgrims but also foreigners and professionals such as soldiers and merchants - not coincidentally, people who displaced themselves regularly. ${ }^{167}$ Foreigners or travellers could not be expected to be fully aware of local legal customs, making summary procedure an accessible and general alternative. ${ }^{168}$ When several regions in Europe established specialised commercial courts throughout the early modern period, they usually relied on summary procedure. ${ }^{169}$ This procedure was different from ordinary civil procedure that was used in European and Dutch civil courts, not only in practical terms but also in the theoretical justification that came from the principles of natural law and equity.

The development of legal procedures in medieval Europe was greatly inspired by canonical law. ${ }^{170}$ One of the first publications that dealt with civil, criminal and canonical procedure was Guillaume Durand's Speculum iudiciale, compiled between 1271 and $1276 .{ }^{171}$ Durand's work was a great influence on the subsequent development of the Roman canonical procedure that came to dominate European civil litigation until the nineteenth century. According to legal scholars, the influence of canonical law on civil litigation can be found in the importance given to written proof, the rational approach to evidence and the secrecy of legal deliberation. ${ }^{172}$ These ideas were very welcome in the

167 See Cerutti, Giustizia sommaria; and Fusaro, 'Politics of justice/politics of trade'. In Venice, foreigners did not have access to the privilege of summary procedure - until it was granted to the English in 1698 - out of consideration for Venetian commercial interests.

168 For these considerations and a discussion of summary procedure in the context of the 'poor' in the Low Countries, see Griet Vermeesch, 'Access to justice: Legal aid to the poor at civil law courts in the eighteenth-century Low Countries', Law and history review, 32:3 (2014): pp. 683-714.

169 See for instance Kessler, A revolution in commerce; see also Knut Wolfgang Nörr, 'Procedure in mercantile matters: Some comparative aspects', in The courts and the development of commercial law, ed. Vito Piergiovanni (Berling, 1987), pp. 195-201; and Alessandro Lattes, Il diritto commerciale nella legislazione statutaria delle città italiane (Milan, 1884).

170 See Kenneth Pennington, The prince and the law, 1200-160o: Sovereignty and rights in the western legal tradition (Berkeley and Oxford, 1993), p. 189; and the part on 'Diritto canonico medievale' in Vito Piergiovanni, Norme, scienza e pratica giuridica tra Genova e l'occidente medievale e moderno (Genoa, 2012), 1: pp. 509-736.

171 Beatrice Pasciuta, 'Durantis, Speculum iudiciale', in The formation and transmission of western legal culture, eds. Serge Dauchy, Georges Martyn, Athony Musson, Heikki Pihlajamäki, and Alain Wijffels (Cham, 2016), pp. 37-40.

172 R.C. van Caenegem, 'History of European civil procedure', in International encyclopedia of comparative law, ed. Mauro Cappelletti (Leiden and Boston, 2014), 16: pp. 3-113 [first published in Tübingen in 1973]. For an analysis of the early modern development of the legality of various methods of proof, see Michael Macnair, The law of proof in early modern equity (Berlin, 1999), which traces the European history of proof from about $155^{\circ}$ to the eighteenth century. 
fragmented European legal environment but did not necessarily deal with the legal basis that litigants could use to substantiate their arguments, nor with the theoretical apparatus judges could use to support their sentencing. This needed to come from the law - whether the abovementioned ius proprium or ius commune.

The ius gentium - a concept from Roman times that meant 'the law of nations' - is similar to the ius commune. It referred to laws applying to Romans and others - which meant it was useful for trade and found its origins in the idea of the law 'which natural reason establishes for all men'. ${ }^{173}$ Several sixteenthand seventeenth-century scholars saw the right to trade freely as part of the ius gentium. Scholars such as Hugo de Groot deemed it a natural right - natural law as a law applicable to all men was a Greek concept but thrived within Christian ideas of universal laws that could not be made by worldly rulers. ${ }^{174}$ While free trade was not withheld as a natural principle, the idea that trade bound men together found strong expression in the work of de Groot and other advocates of natural law: 'for between the contracting parties, there is a closer union than ordinarily obtains [sic] in human society'.175 In a manual on commercial law from the eighteenth century, it is argued that a contract of sale contains three sorts of commitments: first, those explicitly mentioned in the contract; second, those that are natural consequences of the transaction; and third, all those that are ascertained by 'laws, usages or customs.'176 Trade is a form of contract and necessitated legal agreements and security that went beyond the ius proprium, the particular laws of individual territorial states, and belonged to the more universal domain of ius gentium or ius natural, but it nonetheless needed to be congruent with ius proprium.

When Hugo de Groot wrote down his ideas on natural law in De iure belli ac pacis, published in 1625 , he based them on the idea of universal reason, but 'more often than not, reason's precepts happened to be found in the Roman law

173 Benn Steil, 'Globalism and natural law - A brief history', in Natural law, economics and the common good, eds. S. Gregg and H. James (Exeter, 2012), p. 66.

174 For a discussion of the connection between ideas on natural law and the development of international trade after Hugo de Groot, see Martti Koskenniemi, 'International law and the emergence of mercantile capitalism: Grotius to Smith', in The roots of international law/Les fondements du droit international. Liber amicorum Peter Haggenmacher, eds. Pierre-Marie Dupuy and Vincent Chetail (Leiden and Boston, 2013), pp. 1-37.

175 The quote is an English translation from the Latin original and can be found in Hugo Grotius, Hugo Grotius on the law of war and peace, ed. Stephen C. Neff (Cambridge, 2012), p. 205.

176 Lybreghts, Burgerlyk, rechtsgeleerd, notariaal en koopmanshandboek, p. 158, '[...] wetten, gewoontens, of gebruiken [...]'. 
texts of the Digest. ${ }^{177}$ Roman legal tradition allowed for sentencing based on shared rules, beyond ius proprium, and as such, natural law was not separated from it. This is an important consideration when analysing the idea that commercial litigation needed to be judged according to merchant custom. In the early seventeenth century, several English traders and scholars began to refer to a lex mercatoria, or law merchant, as a concept that referred to the universal customs that merchants agreed upon and used to conduct their manner of doing business. This interpretation was made famous by Gerard Malynes, one of the earliest and most vocal supporters of the idea of the law merchant: it 'may well be as ancient as any humane Law, and more ancient than any written Law. The very morall Law it selfe, as written by Moses, was long after the customary law of Merchants, which hath so continued and beene daily augmented successively upon new foundations.'178

Malynes' claims were exaggerated. He was not the first to use the term lex mercatoria, which was used in the English context of the development of royal jurisdiction through the Common Law in the twelfth century at the expense of local courts. It referred to these local courts' use of 'traditional' medieval legal norms and procedures and local competence. The same association with local uses and privileges, which included regulations for the marketplace, led to the use of the term ius mercatorum elsewhere in Europe. In its original meaning, the law merchant did not refer to an international law of merchants but to a multitude of local legal contexts. ${ }^{179}$ The concept was only transformed in the seventeenth century to refer to, and discuss, a universal law of merchants applicable to regulate the development of international trade. Some have suggested that Malynes, a merchant himself, inflated the concept to use in the jurisdictional battles in England during this time, which saw courts concerned with commercial or maritime matters, such as the Court of Admiralty, lose competence to the common law courts, and the latter needed to be newly convinced of the importance of merchant custom in litigation. ${ }^{180}$

177 Benjamin Straumann, Roman law in the state of nature. The classical foundations of Hugo Grotius' natural law (Cambridge, 2015), p. 3. The Digest was one of the three legal compilations that are part of Justinian's corpus iuris civilis. See http://www.thelatinlibrary.com/ justinian.html.

178 Gerard Malynes, Consuetudo, vel lex mercatoria, or the antient law-merchant, divided into three parts: according to the essentiall parts of traffique. Necessarie for all states-men, judges, magistrates, temporall and civile lawyers, mint-men, merchants, mariners, and all others negotiating in all places of the world (London, 1629 [1622]), p. 2.

179 De ruysscher, 'La lex mercatoria contextualisée', pp. 501-504; see also Baker, 'The law merchant'.

180 Maura Fortunati, 'La lex mercatoria nella tradizione e nella recente ricostruzione storicogiuridica', Sociologia del diritto, 32:2-3 (2005): p. 35. For an in-depth analysis of Malynes in 
Some scholars still accept the idea that there was a lex mercatoria and that it carries a long history. While a narrowed-down definition of the concept applied to forms of summary procedure able to deal with (international) commercial litigation - might still be fruitful, the idea of it as a universal and ancient legal system of commercial law based on reason seems ideologically biased as well as wishful thinking. Twentieth-century efforts supporting it can to an extent be summarised as an attempt to provide a historical legitimation of a system that was at some point considered to be the end of history - neoliberalism - and to be able to argue for a historical legal foundation for contemporary commercial globalisation. ${ }^{181}$

Both Malynes' enthusiasm and his claims to universalism should be questioned, as well as the almost timeless nature of the law merchant as hailed by several scholars, but his description is still revealing when considering the importance he attributed to reason and equity in commercial litigation. He concluded his introduction by stating that everything in his work was 'built upon the foundations of reason and justice.'182 When describing the principles of litigation, Malynes asserted that 'the authoritie and proceedings of merchant courts, or priors and consuls, to decide their differences according to equitie in places where they are kept [...]'.183 These aspects belonged, for Malynes, to the 'customarie law of merchants'.184

Carl Günther Ludovici (1707-1778), a German philosopher and economist who published several treatises and lexicons on trade in the second half of the eighteenth century, also mentioned the merchants' style, which he labelled as 'stylus mercatorum' or 'mercatorische Stylus'. ${ }^{185} \mathrm{He}$ used it to refer to 'usages

relation to the law merchant, see Stefania Gialdroni, 'Gerard Malynes e la questione della lex mercatoria', Zeitschrift der Savigny-Stiftung für Rechtsgeschichte, 126 (2009): pp. 38-69.

181 For the links between today and the past, see Oliver Volckart and Antje Mangels, 'Are the roots of the modern lex mercatoria really medieval?' Southern economic journal, 65:3 (1999): pp. 427-450; and Nikitas E. Hatzimihail, 'The many lives - and faces - of lex mercatoria: History as genealogy in international business law', Law and contemporary problems, 71:3 (2008): pp. 169-19o. For an overview of twentieth-century historiography on the matter, see Stefania Gialdroni, 'Il law merchant nella storiografia giuridica del Novecento: una rassegna bibliografica', Forum historiae iuris (2008), consulted at https:// forhistiur.net/2008-o8-gialdroni/?l=it.

182 Malynes, Consuetudo, p. 8.

183 Ibid., p. 7 .

184 Ibid.

185 Carl Günther Ludovici, Grundik eines vollstandigen Kaufmanns-Systeme nebst den Unfangsgründen der Handlungswissenschaft un angehängter turzen Geschichte der Handlung zu Wasser un zu Lande woraus Man zugleich den gegenwärtigen Zustand der Handlung von Europe, auch bis in die andern Welttheile erkennen kann, zum Dienste der Handlungsbeslissenen (Leipzig, 1768), passim. The work was translated into Dutch in 1771. 
and customs' introduced by traders and considered it as one of several sources for commercial law. Ludovici distinguished all sorts of written regulations, ordinances, statues and treatises, including exchange law, the law of the sea, the Hanseatic statutes, particular legislation issued for the trade companies and, importantly, the laws rightfully made by emperors, kings and lords in commerce, 'to which also the Roman laws belong, in the sense that these include many commercial laws, which are still used today in our courts'.186 The main distinction he made between the different sources of commercial law was between legislation that had been written down and legislation that had not, which consisted of usage and custom. Often, when arguing their case in court, merchants referred to this merchants' style. They sued colleagues in court because they had not respected the way in which merchants did things. The argument against the infraction was an argument of reason, as merchant custom had developed on the basis of reason that went beyond the codification of laws by man and stood on the principles of natural rights, exactly as Malynes had described. Considered this way, law merchant is perhaps best described as a term that indicated the use of 'natural law' in the legal evaluation of a merchant's behaviour. And, as shown by Straumann when discussing de Groot's interpretation of natural law, this law did not exist fully separated from the Roman law that was the foundation for the general laws of nations. In short, the idea of a law merchant, defined as a part of natural law that was applicable to adjudication between merchants, fits perfectly within the historical development of the national legal systems, at least in Europe, during the early modern period. In this sense, the merchants' style occupies the same terrain as universal reason governing human action, which is derived from natural law, and the reason of all men of all nations as reflected in the ius gentium. The incorporation of merchant custom in local laws governing trade ensured that the merchants' style can also be traced in the variety of ius proprium. It also means that Ludovici's division between written and unwritten sources for commercial law was perhaps too rigid, as they were more connected than it might seem at first, exactly because of the legal space preserved in Roman law for universal and reasonable principles of law.

The judges best qualified to adjudicate according to principles of commercial law were other merchants, and their importance in specialised commercial courts not only exemplifies the wish for speedy resolution through summary procedure but also confirms the reliance on the merchants' style. In her

186 Ibid., pp. 14-15, '[...] wohin auch die römischen Rechte gehoren, in so sern in denselben gar viele Commerciengesetze enthalten sind, die noch heut in Tage in unsern Gerichten gebrauchet werden'. 
analysis of the Parisian merchant court, Amalia Kessler quoted a 1742 treatise that stated that 'the merchant courts [...] distinguish better than others between the man of good faith and he who wants to deceive.'187 This not only had to do with the merchants-as-judges' knowledge of commercial custom but also with the understanding that they might know the litigating parties personally or obtain personal information about them more easily. ${ }^{188}$ This is more than a logical conclusion deriving from the fact that merchants were judged by their peers. It further connects the adjudicating process to the merchants' style, as successful trade in the early modern period functioned to an important extent on the basis of mechanisms of trust and reputation, expressed through recommendations merchants made to one another, the experience of past transactions, the reciprocity of commercial relations and the establishment of someone's creditworthiness following the growing use of negotiable bills of exchange. ${ }^{189}$ In an early modern Dutch manual on commercial law, the most substantial part of commerce was described as 'the credit, the trustworthiness and the honesty'.190 Natasha Glaisyer has argued that the term 'credit' could refer to three things: 'payments to be made later, one's capacity to pay later, and one's reputation.' ${ }^{191}$ She also stressed that these meanings were all connected, as the capacity to pay was part of the reputation, which was fuelled by the concrete fulfilment of later payments, as well as by the assessment made about other traders' capacities to pay. ${ }^{192}$

The merchants' style can thus be defined as a concept that was applied to indicate the commonly accepted manner in which traders were doing their business. It referred to an often unwritten set of rules, habits, norms and values that were accepted by all involved in commerce to ensure its smooth running. In November 1786, Daniel Jean de Hochepied, Dutch consul in Izmir but also Swedish vice-consul, was asked to consider the claim of a Greek merchant in Amsterdam on the bankrupted house of Avierino \& $\mathrm{C}^{\circ}$, Greek traders who stood under Swedish protection. De Hochepied sent a letter to the Directorate of Levant Trade in which he explained that he had appointed five merchants to investigate the claim and decide upon the merchants' style. ${ }^{193}$ In

\footnotetext{
187 Kessler, A revolution in commerce, p. 66.

188 Ibid.

189 See pp. 293-294.

190 Lybreghts, Burgerlyk, rechtsgeleerd, notariaal en koopmanshandboek, p. 157, '[...] het Crediet, de goede Trouw, en de Eerlykheid'.

191 Glaisyer, The culture of commerce, p. 38.

192 Ibid.

193 Heeringa and Nanninga, Bronnen tot de geschiedenis, 4: pp. 391-392, Consul Daniel Jean de Hochepied to the Directorate of Levant Trade, Izmir, 17/11/1786.
} 
their written arguments submitted before the consular court in Izmir, traders regularly referred to the same merchants' style as a set of rules that had been broken. An uncommon form of insurance could be referred to as 'unknown to the merchants' style', and actions of colleagues could be labelled as 'in conflict with all merchants' style'.194 More than a commonly accepted way of doing business in practice, the merchants' style had legal significance and was, more than any written law, the foundation on which consular judges based their sentencing.

\subsection{Summary Procedure at the Dutch Consular Court of Izmir}

By the mid-eighteenth century, an institutional framework existed that allowed for equitable adjudication of disputes between traders within any Dutch jurisdiction. Judges, whether merchants or aldermen, adjudicated in local courts on the basis of the merchants' style and following summary procedure. ${ }^{195}$ This framework not only applied within the geographical confines of the United Provinces but could be extended to include litigation within Dutch trading communities abroad. In the case of Dutch merchants residing in the Ottoman Empire, their disputes could be adjudicated by the consul and assisted by merchant-assessors because of the establishment of Dutch legal autonomy through the Ottoman capitulations and the Dutch legislation that provided consuls and ambassadors with adjudicating power. ${ }^{196} \mathrm{But}$ was there any specific legislation that codified that these consuls were to adjudicate according to the merchants' style and following summary procedure - or did the specific situation of adjudicating for Dutch merchants who lived abroad and who could get into legal troubles abroad warrant additional legislation?

In 1613, Cornelis Haga sent a letter to the consul in Aleppo, Cornelis Pauw, which included a set of instructions about adjudication. ${ }^{197}$ Haga made it clear that, before accepting litigation, it was the consul's duty to first try to find an agreement between the quarrelling parties; by turning to arbitration, neutral

194 Both were used in a dispute between traders about the financial liability for burned cotton and damaged tobacco; see pp. 146-152.

195 In the early twentieth century, William Mitchell explicitly linked the lex mercatoria, which he defined as 'a kind of ius gentium known to all the merchants throughout Christendom', to the consulate's function as a commercial court. Mitchell, An essay on the early history of the law merchant, p. 1.

196 See pp. 84-95.

197 Heeringa and Nanninga, Bronnen tot de geschiedenis, 1: pp. 1115-1120, 'Ricordo voor den heer Cornelis Pau, Consul van Alleppo', 27/08/1613. 
'good men' had to assess all the evidence to reach a verdict against which no appeal was possible. ${ }^{198}$ Arbitrators were chosen according to a certain procedure, in which both parties were allowed to nominate one (or two), with an additional one nominated by the judges. In any case, parties could, and did, refuse the outcome of arbitration, even though there had to be a promise of acceptance beforehand. 199

When that did not yield any results, the consul was instructed to hear both parties separately and examine all pieces of evidence, including statements by witnesses. The plaintiff had to provide evidence for his claim, otherwise the defendant was acquitted. This was a clear instruction to put the burden of evidence on the plaintiff, and the consul was allowed to dismiss a case at an early stage if there was not sufficient evidence to support the plaintiff's claim. If there was sufficient evidence, the consul should sentence the case, with the help of the assessors. ${ }^{200}$ Cornelis Haga wrote further that the consul had to judge according to the 'custom of our lands, and the lands there [Ottoman Syria], the sea laws, and other ordinances made by the States General or Holland or Zeeland about trade, insurance and other matters. If no specific custom or other legal decision is known, you shall pay attention to equity and

198 For the origins of commercial arbitration, see Fabrizio Marrella and Andrea Mozzato, Alle origini dell'arbitratio commerciale internazionale. L'arbitrato a Venezia tra Medioevo ed età moderna (Padua, 2001); and Sheilagh Ogilvie, Institutions and European trade: Merchant guilds, 1000-1800 (Cambridge, 2011), pp. 296-300. Amalia Kessler has pointed out that arbitration in the context of early modern commercial courts has not been analysed much. Amalia D. Kessler, 'Enforcing virtue: Social norms and self-interest in an eighteenth-century merchant court', Law \& history review, 22:71 (2004): p. 82. Some studies exist, although they do not particularly focus on commercial litigation. For arbitration in late medieval England, see Edward Powell, 'Arbitration and the law in England in the late Middle Ages', Transactions of the Royal Historical Society, 33 (1982): pp. 49-67. For arbitration at Hanseatic courts, see Justyna Wubs-Mrozewicz, 'The late medieval and early modern Hanse as an institution of conflict management', Continuity and change, 32:1 (2017): pp. 59-84. For the use of arbitration in civil law disputes in an early modern Dutch city, see A.P.B. van Meeteren, Op hoop van akkoord. Instrumenteel forumgebruik bij geschilbeslechting in Leiden in de zeventiende eeuw (Hilversum, 2006), pp. 226-273. For a good analysis of the role played by the Dutch and English legal habits of arbitration in commercial disputes in eighteenth-century New York, see Eben Moglen, 'Commercial arbitration in the eighteenth century: Searching for the transformation of American law', The Yale law journal, 93:1 (1983): pp. 135-152.

199 For an example of an attempt at arbitration to settle a commercial dispute, see the analysis of the quarrel between Thomas de Vogel \& Zoon and Clement, van Sanen, van der Zee \& $\mathrm{C}^{\circ}$ on pp. $146-152$.

200 Heeringa and Nanninga, Bronnen tot de geschiedenis, 1: pp. 1115-1120, 'Ricordo', 27/o8/1613. 
natural justice.'201 The last phrase is very important, as it was natural law that served as the underpinning of the merchants' style and summary procedure.

The documents preserved in the archives of the consular court allow for a good understanding of the practical mechanisms behind litigation. First, a merchant made a request, in which he briefly laid out his claim. In the margins, the consul and assessors noted their comments and instructed the chancellor to inform the defendant and provide him with a specific timeframe within which he had to provide his answer. After this, a dialogue of replies and counter-replies took place. As a rule, the replies and counter-replies were labelled by using the official legal terminology for them: replyq, duplyq, triptycq. The cases brought before the Dutch consul in Izmir counted several rounds of these dialogues - there was space for that in the legislation. ${ }^{202}$

These were not the only documents used in these cases. Written evidence was also admitted. This varied from expert reports and witness statements to excerpts from business books or commercial correspondence. These could be specifically demanded by the consul and assessors or produced by one of the parties within the framework of an argument. Their veracity had to be checked by the court before their admission in the case at hand. Haga summed up the three types of evidence the consul should allow: witness statements, instruments and strong presumptions. ${ }^{203}$ Witnesses had to be asserted as neutral, honest and of good repute and needed to be at least two in number. ${ }^{204}$ When the consul interrogated a witness, he should ask questions about the concrete case as well as about the wider context. He also had to make sure to exclude the witness declaration as coming from hearsay, as that rendered it invalid. It is clear that Haga's instruction to the consul was a first and important effort to codify procedures abroad, which is why he specifically asked Pauw to find out whether the consuls of other European nations allowed for witness statements made by 'Turks or Jews' ('Turcken off Joden') and whether their adherence to

201 Ibid., p. 1118, '[...] costuyme van onse en de landen aldaer, op de seerechten, sij andere placaten, bij mijnheeren de Staeten-Generael ofte Hollandt Seelant gemaect aengaende de negotie, soo van assurancie al sanders, die U.E. dienstich sullen sijn te ontbieden. Bovendien geen notoire costume ofte andere decisie van rechten U.E. bekent sijnde, sult principaelijck letten op de natuerlijcke billicheyt van de saeke ende van't recht [...]'.

202 See p. 122.

203 Heeringa and Nanninga, Bronnen tot de geschiedenis, 1: pp. 1115-1120, 'Ricordo', 27/o8/1613, on p. 1117 .

204 Ulrik Huber, Heedensdaegse rechtsgeleertheyt, soo elders, als in Frieslandt gebruikelijk, 3rd ed. (Amsterdam, 1779), pp. 792-804 defines a number of necessary conditions for the use of witnesses in legal procedure. 
their own religion was a sufficient reason to consider them trustworthy. ${ }^{205}$ This was an important remark, considering the significance of the oath as a tool to establish the veracity of declarations: 'so the books of merchants, the matters therein about handling and delivering the goods were known, with good distinction of persons, affairs, year, month and day, are given full belief, if they are strengthened by oath'. ${ }^{206}$ In one particular case brought before the consul in Izmir, a Dutch plaintiff declared himself willing to abandon a claim against Greek merchants if they were willing to take an oath in the presence of the Greek bishop, with their hands on the Bible. ${ }^{207}$ The 158 o Ordonnantie published thirty-three years before Haga wrote his instruction - contained a clause that specified that witness statements not supported by an oath were not valid in court. ${ }^{208}$ As a general rule, Pauw was allowed to use the example of other European consuls in his manner of adjudication, particularly in a dispute between a Dutchman and a foreigner.

The second type of evidence Haga mentioned, 'instruments', consisted of public and private written documents. Public documents were drafted before a notary and witnesses at the consular chancery or in any court - this automatically validated their legal use. Private documents included all sorts of written documents made outside the public sphere or without help from a public official. Commercial correspondence and a merchant's business books were private documents, which meant they were not legally valid per se. Handwriting needed to be verified and the content of business books needed to be confirmed by an oath taken by the merchants to whom they belonged. In his comments on the 1580 ordinance that regulated civil procedure in Holland, Simon van Leeuwen wrote that it was a 'general custom' ('volgens generale costuymen') in Holland to accept business books in court. ${ }^{209}$ When the legality of such documents had been verified, they could be used in court, similar to

205 Heeringa and Nanninga, Bronnen tot de geschiedenis, 1: pp. 1115-1120, 'Ricordo', 27/08/1613, on p. 1117 .

206 Decker, Het Roomsch Hollandsch recht, 2: p. 443, 'So werden ook de boeken van koopluiden, van saken daar van de handeling en levering van het goed bekend werd, met goed onderscheid van personen, saken, jaar, maand, en dag gehouden, in het verder volkomen geloof gegeven, so die met eede gesterkt [...]'. A different religious background was sometimes considered problematic, while in other instances it was immediately accepted. See Francisco Apellániz, “'You cannot produce a Muslim witness”: Early Ottoman attitudes towards proof and religious difference', in 'Litigation and the elements of proof in the Mediterranean (16th-19th c.)', eds. Wolfgang Kaiser and Johann Petitjean, Quaderni storici, special issue, 3 (2016): pp. 633-648.

207 See p. 297.

208 'Ordonnantie op 't stuk van de justitie', p. 70.

209 Ibid., p. 28. 
'public instruments' ('publyque instrumenten') and debt declarations. ${ }^{210}$ Once the instruments were accepted, they could be used to issue a temporary verdict (bij provisie), in which the defendant was condemned to deposit a security in the chancery worth the same amount as the plaintiff's claim before the dispute would be adjudicated fully (ten principale), resulting in a sentence. ${ }^{211}$

Haga's third category of evidence were presumptions (presumtiën). Legally, these were defined as 'probable causes' able to explain the facts after they had been established. Haga wrote that there were too many different presumptions to be written down, but scholars divided them into two categories. A strong presumption meant the party accused of wrongdoing had to prove the opposite. Under a light presumption, the role of the judge in assessing the evidence is more important. ${ }^{212}$ Haga used these categories and indicated to Pauw that a very strong presumption was sufficient for the consul to consider the accusation proven. For less strong presumptions, the consul was allowed to take the oath from the person against whom the presumption was made. Should that person swear the presumption was wrong, the consul could acquit him, a mechanism that once again demonstrates the importance of the oath as a legal instrument to support or discard evidence. ${ }^{213}$ Once all information had been gathered, the judges had to reach their verdict, which could be temporary or definitive. A temporary verdict was subject to change in cases where new information was provided, while a definitive verdict could only be changed through an appeal procedure at the competent court. ${ }^{214}$

Two years after Haga's letter, Cornelis Pauw sent a letter of his own from Aleppo to the States General in which he remarked that as far as adjudication was concerned, the European consuls were following the 'usages of these [Ottoman Syrian] lands. ${ }^{215}$ This might have been an answer to Haga's request for information about the use of witness statements by other European consuls. ${ }^{216}$ It is clear from the content of Pauw's letter that he referred to the nonexistence of lawyers or attorneys in the Ottoman context and the fact that the

\footnotetext{
210 Ibid.

211 Heeringa and Nanninga, Bronnen tot de geschiedenis, 1: pp. 1115-1120, 'Ricordo', 27/o8/1613, on p. 1117 .

212 Huber, Heedensdaegse rechtsgeleertheyt, pp. 8o5-8o6.

213 Heeringa and Nanninga, Bronnen tot de geschiedenis, 1: pp. 1115-1120, 'Ricordo', 27/08/1613.

214 Ibid.

215 Heeringa and Nanninga, Bronnen tot de geschiedenis, 1: pp. 468-478, Consul Cornelis Pauw to the States General, Aleppo, 12/og/1615, on p. 469, '[...] nae de usantie van dese landen $[\ldots]$ '.

216 Which he made in Heeringa and Nanninga, Bronnen tot de geschiedenis, 1: pp. 1115-1120, 'Ricordo', 27/08/1613.
} 
trial was oral rather than in writing. Legal procedure, according to Pauw, was limited to hearing the litigants and witnesses and discussing written documents brought in as evidence, after which a sentence was pronounced orally. Pauw continued that 'this short style is necessary, because most disputes consist of misunderstandings between the buyer and seller, or a sinister interpretation of the brokers, also serving as interpreters, or also in the forgery of merchandise, deception and other differences regarding commerce, which demand to be settled immediately'. ${ }^{217}$ What Pauw is describing is clearly a form of summary procedure ('short style'), and it is very similar to how Simon van Leeuwen described it half a century later. ${ }^{218}$ It is possible that Cornelis Pauw, who received criticisms for being unexperienced, considered this sort of procedure as particularly 'Ottoman', even though it was not.

Even if Pauw was wrong about the origins of this summary procedure, he was not necessarily wrong in labelling them as Ottoman. Non-European courts also adopted forms of summary procedure. Evidence shows that the local seventeenth- and eighteenth-century Ottoman qadi courts relied less on written statements than on oral presentations of the arguments. This, however, did not mean that written documents were not relied upon or had no legal weight. They rather 'complemented the claims and allegations made by the litigants in court $[\ldots]$ these texts were designed to make space for the oral performance of the participants in the court process. ${ }^{219}$ This practice is not as different from the summary procedure used in the Dutch consular court in Izmir as it might seem. In theory, the role of written evidence was to support the claims that had been made. In the courts Boğaç Ergene studied, these claims were made orally and in person. In the consular court, it was done in writing, through the

217 Heeringa and Nanninga, Bronnen tot de geschiedenis, 1: pp. 468-478, Consul Cornelis Pauw to the States General, Aleppo, 12/og/1615, on p. 469, 'Dese corte stijl is te meer noodich, omdat de meeste questiën, die voorvallen, bestaen in misverstanden tusschen den cooper ende verkooper, door de sinistre interpretatie van de maeckelaers, gelijcksam voor taelmans dienende, item in vervalsinge van de coopmanschappen, bedroch ende andere differenten betreffende 't stuck van de negotie, dewelcke verheyschen datelijck worden gedecideert [...]'.

218 See p. 121.

219 Boğaç A. Ergene, 'Evidence in Ottoman courts: Oral and written documentation in earlymodern courts of Islamic law', Journal of the American Oriental Society, 124:3 (2004): p. 487. For the notion that Eurocentric criticisms of how the Ottoman court functioned were unfounded, see Metin M. Coşgel and Boğaç A. Ergene, 'Dispute resolution in Ottoman courts: A quantitative analysis of litigations in eighteenth-century Kastamonu', Social science history, 38 (2014): pp. 183-202; Boğaç A. Ergene, Local court, provincial society and justice in the Ottoman Empire. Legal practice and dispute resolutions in Çankiri and Kastamonu (1652-1744) (Leiden and Boston, 2003). 
system of replies and counter-replies. This was not just a matter of attributing more weight to the written word, it was also a consequence of long-distance trade; merchants could not be expected to appear in court personally, so it was a pragmatic choice to allow them to hand in written declarations. These were often compiled in a style that might as well have been oral, with sometimes hefty, emotional language, the building up of long narratives containing an argument that, more often than not, centred around the behaviour and degree of responsibility of the defendant. 